PAULINA MATERA

https://orcid.org/0000-0001-5453-1622

Katedra Amerykanistyki i Mass Mediów Uniwersytetu Łódzkiego

RAFAE MATERA

https://orcid.org/0000-0003-3683-0439

Katedra Historii Myśli Ekonomicznej i Historii Gospodarczej Uniwersytetu Łódzkiego

\title{
W CZTERDZIESTOLECIE SANKCJI WOBEC IRANU. ANALIZA PRZYCZYN I SKUTKÓW POLITYCZNO-GOSPODARCZYCH: 1979-2019
}

Zarys treści: Artykuł ma na celu ocenę skuteczności sankcji stosowanych przez państwa Zachodu wobec Iranu w okresie 40 lat (1979-2019). We wstępie postawiono hipotezę, że skoordynowane sankcje Stanów Zjednoczonych i państw europejskich mogą doprowadzić do osiagnięcia głównego celu wobec Iranu: ograniczenia programu nuklearnego rozwijanego przez to państwo. Program ten był postrzegany przez Zachód jako poważne zagrożenie bezpieczeństwa międzynarodowego. Przedstawiono powody nałożenia sankcji na Iran przez USA, ewolucje stanowiska europejskiego wobec ich stosowania oraz mechanizmy i skutki współpracy państw Zachodu w wywieraniu presji gospodarczej na Iran. Oceniono realizację amerykańskich i europejskich celów sankcji, tak, by zrozumieć powody wycofania się w 2018 r. Stanów Zjednoczonych z podpisanego w 2015 r. porozumienia z Iranem.

The content outline: The article aims to evaluate the effectiveness of sanctions administered by Western countries against Iran over a period of forty years (1979-2019). It is hypothesised that coordinated sanctions by the United States and European countries could enable them to achieve the main goal: curtail Iran's nuclear programme, which is perceived by the West as a serious threat to international security. The paper presents the reasons for the United States imposing sanctions on Iran, the evolution of the European position on the validity of their administration, and the mechanisms and effects of Western countries' cooperation in exerting economic pressure on Iran. It also evaluates the implementation of U.S. and European sanction objectives in order to determine the reasons for the withdrawal of the United States in 2018 from the 2015 agreement signed with Iran. 
Słowa kluczowe: sankcje USA, ONZ i UE wobec Iranu, współpraca transatlantycka, Wspólny Kompleksowy Plan Działania, przyczyny sankcji, skutki sankcji

Keywords: U.S., UN and EU sanctions against Iran, transatlantic cooperation, Joint Comprehensive Plan of Action, reasons for sanctions, effects of sanctions

\section{Wstęp}

Rozwijanie przez Iran programu nuklearnego jest jednym z ważniejszych zagadnień współczesnego bezpieczeństwa międzynarodowego. Państwa zachodnie obawiaja się, że ma on charakter militarny, co może spowodować destabilizację na Bliskim Wschodzie. Władze w Teheranie utrzymują natomiast, że program ten rozwijany jest tylko do celów pokojowych, do czego maja prawo na podstawie traktatu o nierozprzestrzenianiu broni jądrowej ${ }^{1}$. Jednak zarówno Stany Zjednoczone, jak i Unia Europejska podejmują działania w celu skłonienia Iranu do zaprzestania wzbogacania uranu oraz poddania programu nuklearnego międzynarodowej kontroli. Żeby wywrzeć presję na władze irańskie, stosują sankcje gospodarcze. USA używały tego narzędzia od początku lat osiemdziesiątych XX w., UE zdecydowała się je wprowadzić dopiero po rezolucji Rady Bezpieczeństwa ONZ (RB ONZ) z grudnia 2006 r., koordynując działania z USA.

Celem artykułu jest weryfikacja hipotezy, że sankcje nakładane wyłącznie przez Stany Zjednoczone nie odnoszą skutku w postaci skłonienia Iranu do spełnienia postulatów Zachodu. Natomiast współpraca transatlantycka w tej kwestii sprawia, iż sankcje sa na tyle dotkliwe, że teherański reżim jest skłonny do ustępstw. Według Johana Galtunga jednym z kluczowych warunków skutecznego wywarcia nacisku ekonomicznego jest sytuacja, kiedy eksport do państw, które nakładają sankcje, jest bardzo istotny dla stabilności gospodarki podlegającej sankcjom. Jednocześnie karane restrykcjami państwo to nie ma dużych możliwości dywersyfikacji eksportu2 ${ }^{2}$. W przypadku Iranu głównymi dobrami eksportowymi są ropa i gaz ziemny. Ponieważ sankcje amerykańskie na Iran zostały wprowadzone w latach osiemdziesiątych XX w., Iran nie eksportował na ten rynek surowców. Z kolei państwa europejskie były ich ważnymi odbiorcami. Działając wspólnie, Stany Zjednoczone i państwa

1 A.A. Gul, Iran's Pursuit of Peaceful Nuclear Technology, „Pakistan Horizon” 65, 2012, nr 1, s. 35-52.

2 J. Galtung, On the Effects of International Economic Sanctions. With Examples from the Case of Rhodesia, „World Politics” 19, 1967, s. 384. 
europejskie mogły osłabiać gospodarkę Iranu także na innych polach (np. ograniczając jego dostęp do rynków finansowych) oraz wywierać presję na inne państwa, by ograniczały swe kontakty z Iranem. Poza tym Zachód wzmacniał w ten sposób swoją pozycję w negocjacjach prowadzonych w tym samym czasie z Teheranem.

Przed oceną działania sankcji należy najpierw określić, jaki mają one odnieść skutek. W tym celu zastosowaliśmy metodę Lee Jonesa i Clary Porteli, która zakłada, że sankcje mają wiele celów. Można je ustalić na podstawie obserwacji konkretnych wydarzeń i decyzji (przed i po wprowadzeniu sankcji) oraz dostępnych dokumentów ${ }^{3}$.

Także Francesco Giumelli postulował szersze spojrzenie na skuteczność sankcji. Stwierdził, że ich jedynym celem nigdy nie jest zmiana konkretnej polityki danego państwa, ale poddanie go przymusowi, ograniczenie możliwości podjęcia określonych działań w polityce wewnętrznej i zagranicznej oraz wyrażenie potępienia i nałożenia kary. Zauważył, że należy brać pod uwagę wszystkie okoliczności, które kształtuja sposób wprowadzania sankcji i ich charakter - ważne w tym przypadku sa cele, ale także specyfika państwa, które jest przedmiotem sankcji. Podkreślał, że skala strat gospodarczych, jakie ono ponosi, nie jest równoznaczna z sukcesem sankcji. W tym przypadku należy również ocenić, czy pogarszają się wskaźniki ekonomiczne oraz warunki życia obywateli, czy skutki mają charakter długoterminowy - w postaci zablokowania możliwości rozwoju. Ważne jest również, czy dane państwo przejawia wolę kompromisu w trakcie prowadzonych w tym czasie negocjacji ${ }^{4}$.

Według tego badacza proces oceny skuteczności sankcji należy podzielić na cztery etapy: 1) umieścić je w szerszym kontekście polityki zagranicznej podmiotów nakładających sankcje, 2) określić cele sankcji przed ich nałożeniem, 3) ocenić realizację założonych celów, a także 4) zasadność sankcji w porównaniu do innych dostępnych narzędzi polityki zagranicznej. Ta metoda zostanie zastosowana przy ocenie skuteczności sankcji nakładanych na Iran wyłącznie przez USA oraz w porównaniu ze skutecznością restrykcji nakładanych w koordynacji z UE.

${ }^{3}$ L. Jones, C. Portela, Evaluating the "Success" of International Economic Sanctions. Multiple Goals, Interpretive Methods and Critique, „Research Collection School of Social Sciences" 2014, nr 1671, https://ink.library.smu.edu.sg/cgi/viewcontent. cgi?article=2928\&context=soss_research (30 IX 2021).

${ }^{4}$ F. Giumelli, The Success of Sanctions. Lessons Learned from the EU Experience, Farnham 2013, s. 7-14.

5 Tamże, s. 9. 


\section{Powody nałożenia amerykańskich sankcji na Iran w XX w. Stanowisko państw europejskich}

Osłabione po II wojnie światowej państwa europejskie szybko przekonały się, że nie były w stanie utrzymać kolonii. Liczyły na pomoc Stanów Zjednoczonych, jednak Amerykanie woleli pozyskać nowo powstające państwa poprzez związki ekonomiczne, które mogły w przyszłości przerodzić się we współpracę polityczna. Przede wszystkim nie chciano dopuścić do rozciagnięcia na tych obszarach wpływów radzieckich. Jednym z najważniejszych strategicznie regionów był dla USA Bliski Wschód. Kiedy władzę w Iranie w 1951 r. przeją Mohammad Mosaddegh, zdecydował się na nacjonalizację produkcji ropy naftowej, co bezpośrednio uderzyło $\mathrm{w}$ interesy brytyjskie. Wówczas plany interwencji zbrojnej rządu brytyjskiego zostały zahamowane przez naciski strony amerykańskiej. W wyniku przewrotu inspirowanego przez CIA w sierpniu 1953 r. Mosaddegh został obalony i zastapiony generałem Fazlollahem Zahedim - przychylnym porozumieniu z Amerykanami. W utworzonym Międzynarodowym Konsorcjum Naftowym korporacje amerykańskie uzyskały udziały równe brytyjskim (po 40\%). Był to przykład wypierania wpływów europejskich, jednak Brytyjczycy pogodzili się $\mathrm{z}$ tym faktem, gdyż w pojedynkę nie byli już w stanie eksploatować irańskiej ropy na dotychczasowych zasadach ${ }^{6}$.

O wzroście znaczenia Iranu dla Stanów Zjednoczonych jako ważnego sojusznika w regionie świadczył eksport broni do tego państwa w latach sześćdziesiątych XX w. Obok Arabii Saudyjskiej był on głównym filarem bezpieczeństwa w rejonie Zatoki Perskiej. Waszyngton popierał rządy szacha Mohammada Rezy Pahlawiego. W 1978 r. dyktator zakupił wielką transzę amerykańskiej broni, ale też produkty nowoczesnej technologii, planując szybką modernizację. Były to dla Amerykanów bardzo korzystne kontrakty, także pod względem gospodarczym. Jednak wskutek nasilających się jesienią 1978 r. masowych protestów szach opuścił Iran w styczniu 1979 r. W kolejnym miesiącu do Iranu powrócił z emigracji szyicki duchowny - ajatollah Ruhollah Chomejni. 11 II 1979 r. przejął on faktyczną władzę w państwie jako zwierzchnik religijny proklamowanej Islamskiej Republiki Iranu.

Największym ciosem dla Stanów Zjednoczonych było jednak uwięzienie w listopadzie 1979 r. amerykańskich zakładników w teherańskiej ambasadzie. Wydarzenia w Iranie odcięły USA, uznawane przez

${ }^{6}$ W. LaFeber, American Age. United States Foreign Policy at Home and Abroad since 1750, New York 1989, s. 518. 
radykałów religijnych za „państwo szatańskie”, od pewnego źródła ropy naftowej i zachwiało amerykańska polityka bezpieczeństwa w tym regionie świata. Spowodowało także kolejną zwyżkę cen ropy, co uderzyło nie tylko w USA, ale również w państwa europejskie, w dużym stopniu zależne od irańskich dostaw ${ }^{7}$. Uwięzienie zakładników było kluczowym powodem nałożenia w listopadzie 1979 r. pierwszych sankcji na Iran przez rząd USA. Dotyczyły one blokady irańskiego rządowego majątku zdeponowanego w USA i transferów broni. Dekret prezydencki (nr 12170) ${ }^{8}$ Jimmy'ego Cartera zakładał zamrożenie 12 mld USD irańskich aktywów, w tym depozytów bankowych, złota i innych własności oraz embargo handlowe. Stany Zjednoczone przekonywały społeczność międzynarodowa, zwłaszcza partnerów europejskich, do przyłączenia się do tej polityki. Mimo deklaracji solidarności, państwa europejskie nie przyłączyły się do bojkotu irańskiej ropy i nałożenia sankcji. Niepokojono się, że Carter pod wpływem nacisków opinii publicznej zdecyduje się na działania zbrojne na Bliskim Wschodzie, co mogło sprowokować wojnę ze Związkiem Radzieckim ${ }^{9}$ Chcąc odbić zakładników, Carter zdecydował się wysłać w kwietniu 1980 r. misję ratunkowa. Akcja sześciu helikopterów zakończyła się jednak niepowodzeniem. Ostatecznie zakładnicy zostali uwolnieni dopiero 20 I 1981 r., w dniu przejęcia władzy przez Ronalda Reagana ${ }^{10}$.

W październiku 1983 r. doszło w Bejrucie do samobójczego ataku na koszary międzynarodowych sił pokojowych, w którym zginęło 241 amerykańskich żołnierzy. W związku z podejrzeniami administracji Reagana, że władze w Teheranie wspierały zamach, Amerykanie zdecydowali o zakwalifikowaniu Iranu jako „państwa sponsorujacego terroryzm”. Nałożono kolejne sankcje: zakazano udzielania pożyczek i pomocy rozwojowej oraz ograniczono sprzedaż technologii i materiałów „podwójnego zastosowania", które mogłyby być wykorzystane w działaniach militarnych. Z drugiej strony nielegalnie (bez wiedzy Kongresu) administracja amerykańska wyrażała zgodę na dostarczanie broni Iranowi, który od września 1980 r. prowadził wojnę z Irakiem. W rozmowach

${ }^{7}$ Kryzys w Iranie uruchomił perturbacje w gospodarce światowej. Wywołany polityka OPEC drugi szok naftowy miał miejsce w latach 1979-1980. Ceny ropy wzrosły ponad dwukrotnie, przebijając 30 USD za baryłkę; więcej zob. J. Skodlarski, R. Matera, Gospodarka światowa. Geneza i rozwój, Warszawa 2004, s. 273.

${ }^{8} \mathrm{https} / / / \mathrm{www} . t r e a s u r y . g o v /$ resource-center/sanctions/Programs/Documents/Executive\%20Order\%2012170.pdf (14 IV 2020).

${ }^{9}$ L.P. Bloomfield, Crisis Management Outside the NATO Area. Allies or Competitors?, w: Allies in a Turbulent World. Challenges to U.S. And Western European Cooperation, red. F.A.M. Alting von Geusau, Lexington 1982, s. 52.

${ }_{10}$ W. LaFeber, dz. cyt., s. 662. 
w 1985 r. na temat sprzedaży rakiet Hawk brał udział sam prezydent Reagan. Ta tzw. afera Iran-Contras wyszła na światło dzienne w listopadzie 1986 r. po ujawnieniu, że środki z transakcji broni (niemal połowa ze 100 mln USD) uzyskała prawicowa partyzantka Contras działająca w Nikaragui. W 1987 r. Reagan zdecydował się nałożyć embargo na import z USA do Iranu ${ }^{11}$. Od tego momentu Stany Zjednoczone miały ograniczone możliwości wpływu gospodarczego na Iran. Jeśli weźmiemy pod uwagę, że stosunki dyplomatyczne między tymi dwoma państwami zostały zerwane w kwietniu 1980 r., nie było także szans na prowadzenie oficjalnych, dwustronnych negocjacji.

Cele amerykańskich sankcji zmieniały się w czasie. Pierwotnie miały one zmusić Iran do zaprzestania wspierania aktów terrorystycznych i zredukować jego wpływy na Bliskim Wschodzie. Jednak od połowy lat dziewięćdziesiątych XX w. największy nacisk położono na uniemożliwienie Iranowi rozwoju militarnego programu nuklearnego. W $1995 \mathrm{r}$. w odpowiedzi na intensyfikację irańskich prac nad tym programem oraz ze względu na wspieranie organizacji terrorystycznych: Hezbollahu, Hamasu i Islamskiego Dżihadu, Bill Clinton zdecydował się na ogłoszenie dwóch rozporządzeń wykonawczych. Pierwsze z nich $(\mathrm{nr} 12957)^{12}$ z 15 marca zakazywało inwestycji w irański sektor energetyczny, drugie $(\mathrm{nr} 12959)^{13} \mathrm{z} 6$ maja zakazywało handlu i inwestycji w Iranie. Oficjalnie ILSA (Iran and Libya Santions Act) został podpisany 5 VIII 1996 r. $^{14}$

Państwa UE były ważnymi partnerami handlowymi Iranu, który chętnie pozyskałby europejskie inwestycje i technologię. Dlatego członkowie UE zdecydowanie sprzeciwiali się ekspansji amerykańskich sankcji. Prowadzili odrębna politykę wobec Iranu, utrzymywali stosunki dyplomatyczne i gospodarcze z Teheranem w ramach „krytycznego dialogu”. Terminu tego użył prezydent Francji Jacques Chirac w 1996 r., wskazując, że dialog „nie jest otwarty i przyjazny, taki jak z państwami, z którymi mamy normalne stosunki handlowe, kulturowe i polityczne. Jest to ograniczony dialog, dzięki któremu Europejczycy przekazują Iranowi rozwiąania w dziedzinie praw człowieka"15. Państwa europejskie

\footnotetext{
${ }_{11}$ The Iran-Iraq War. The Politics of Agression, red. F. Rajaee, Gainesville 1993.

12 https://www.treasury.gov/resource-center/sanctions/Documents/12957.pdf (14 IV

${ }^{13}$ https://www.treasury.gov/resource-center/sanctions/Documents/12959.pdf (14 IV

${ }^{14}$ W 2006 r. został on przekształcony na ISA Act (Iran Sanctions Act) w momencie zdjęcia sankcji z Libii.

${ }_{15}$ R.S. Litwak, Rogue States and US Foreign Policy. Containment after the Cold War, Washington 2000, s. 83 (jeżeli nie zaznaczono inaczej, tłumaczenia są dziełem autorów).
} 2020). 2020). 
stosowały zatem zachęty ekonomiczne (kredyty handlowe czy restrukturyzację zadłużenia), aby zmieniać politykę reżimu. USA zniechęcały strony trzecie do stosunków gospodarczych z Iranem poprzez nałożenie wtórnych (eksterytorialnych) sankcji na europejskie przedsiębiorstwa inwestujące $\mathrm{w}$ irańską infrastrukturę produkcji ropy naftowej i gazu ziemnego. Po silnych protestach europejskich amerykańskie sankcje wtórne nie były jednak w praktyce egzekwowane ${ }^{16}$.

W 1997 r. Mohammad Chatami, uważany za zwolennika dialogu z Zachodem, wygrał wybory prezydenckie w Iranie. UE wezwała wtedy Teheran do negocjacji w ramach „kompleksowego dialogu”, uwzględniającego kwestie polityczne, energetyczne i handlowe. Także Stany Zjednoczone wzięły udział w nieformalnej inicjatywie ONZ, działającej w latach 1997-2001 grupie 6+2 (6 państw graniczących z Afganistanem: Chiny, Pakistan, Iran, Tadżykistan, Turkmenistan i Uzbekistan oraz Stany Zjednoczone i Rosja), która miała na celu koordynację działań względem Afganistanu ${ }^{17}$.

W 2000 r. rozmowy te zostały zerwane. Nieskuteczne okazały się jednostronne sankcje amerykańskie, żadnych rezultatów nie przyniósł też dialog w grupie 6+2 ani prowadzony przez stronę europejska. Jednak dramatyczna sytuacja międzynarodowa w $2001 \mathrm{r}$. związana $\mathrm{z}$ atakiem z 11 września Al-Kaidy na World Trade Center i Pentagon oraz ogłoszona przez amerykańskiego prezydenta George’a W. Busha „wojna z terroryzmem” doprowadziły do zmian w strategii wobec Iranu.

\section{Polityka USA i UE w pierwszej dekadzie XXI w.}

W 2002 r., kiedy społeczność międzynarodowa dowiedziała się o wzbogacaniu uranu w okolicach irańskiego Natanz, UE bardziej zaniepokoiła się rozwojem irańskiego potencjału nuklearnego. Można było odtąd zauważyć zmianę podejścia do sankcji amerykańskich ${ }^{18}$. Poza tym po amerykańskiej inwazji na Irak w 2003 r. UE obawiała się, że irańskie obiekty jądrowe moga stać się kolejnym celem dla USA i Izraela.

${ }_{16}$ P. Dupont, The EU-Iran Dialogue in the Context of the Ongoing Nuclear Crisis, „The Central European Journal of International and Security Studies” 3, 2010, nr 1, s. 97-112, http://www.cejiss.org/issue-detail/the-eu-iran-dialogue-in-the-context-of-theongoing-nuclear-crisis (30 IX 2021).

17 Więcej na ten temat zob. M.H. Sadat, J.P. Hughes, U.S.-Iran Engagement Through Afghanistan, „Middle East Policy Council” 17, 2010, nr 1, s. 31-51.

${ }_{18}$ R. Patterson, EU Sanctions on Iran. The European Political Context, „Middle East Policy" 20, 2013, nr 1, s. 137. 
Aby uniknąć tego scenariusza, zaczęto brać pod uwagę możliwość nałożenia sankcji na Iran, co mogło powstrzymać USA od militarnego ataku na to państwo, umieszczone przez Busha wraz z Irakiem i Koreą Północną na „osi zła” ${ }^{2}$.

Francja, Niemcy i Zjednoczone Królestwo w ramach tzw. grupy EU3 prowadziły negocjacje z Iranem. W 2003 r. zaproponowały Irańczykom korzyści gospodarcze w zamian za zaprzestanie wzbogacania uranu ${ }^{20}$. Rozmowy zakończyły się podpisaniem dwóch deklaracji: paryskiej i teherańskiej z lat 2003 i 2004. Umowy te zostały opracowane z myślą o doprowadzeniu do rezygnacji przez Iran z militarnego programu nuklearnego oraz zwiększeniu bezpieczeństwa w regionie. Strony nie mogły jednak dojść do porozumienia w kwestii tego, czy Iran ma prawo do wzbogacania uranu na swoim terytorium do celów pokojowych (energetycznych). Od listopada 2004 r. do negocjacji EU3 z Iranem dołączył wysoki przedstawiciel UE ds. wspólnej polityki zagranicznej i bezpieczeństwa Javier Solana, a jego następczynie (Catherine Ashton i Federica Mogherini) również aktywnie uczestniczyły w dalszych rozmowach ${ }^{21}$. Władze w Teheranie były natomiast rozczarowane brakiem zaangażowania przedstawicieli USA ${ }^{22}$. W styczniu 2006 r. władze irańskie zdecydowały o usunięciu pieczęci założonych przez Międzynarodową Agencję Energii Atomowej (MAEA) z ośrodka w Natanz. Rada Europejska uznała to za pogwałcenie wcześniejszych porozumień. Uznano, że „przyszedł czas, aby Rada Bezpieczeństwa ONZ zaangażowała się w egzekwowanie postanowień MAEA"23.

Czas rzeczywiście wydawał się dogodny, gdyż Chiny i Rosja poczuły zagrożenie i były gotowe zmienić dotychczasowe stanowisko. Przed 2006 r., jako stali członkowie RB ONZ, konsekwentnie sprzeciwiali się wydaniu rezolucji nakładajacej sankcje na $\operatorname{Iran}^{24}$. Grupa P5+1 - pięciu

19 S. de Galbert, Back to the Future. Europe, the United States, and Iran Sanctions after the Nuclear Deal, 15 XI 2015 r., https://www.csis.org/analysis/back-future (30 IX 2021).

20 T. Cronberg, No EU, No Iran Deal. The EU's Choice between Multilateralism and the Transatlantic Link, „The Nonproliferation Review” 24, 2017, nr 3-4, s. 246.

${ }^{21}$ G. Martin, European Diplomacy and the Iranian Nuclear Negotiations, http:// www.europeaninstitute.org/index.php/252-european-affairs/ea-may-2015/2066-autogenerate-from-title (30 IX 2021).

${ }^{22}$ R. Fiedler, Iran a reżim nieproliferacji broni jadrowej. Dylematy $i$ wyzwania, Poznań 2013, s.107-108.

${ }^{23}$ Statement by Germany, United Kingdom, France and the EU High Representative on the Iranian nuclear issue, 12 I 2006 r., https://www.consilium.europa.eu/ueDocs/ cms_Data/docs/pressdata/EN/declarations/87970.pdf (30 IX 2021).

${ }^{24}$ R. McMahon, Iran, the United Nations, and Sanctions, 4 IV 2006 r., https://www. cfr.org/backgrounder/iran-united-nations-and-sanctions (30 IX 2021). 
stałych członków RB ONZ oraz Niemcy - próbowała wypracować kompromis w sprawie zakresu sankcji, które mogłyby zostać nałożone w przypadku, gdyby Iran nie spełnił postulatów.

Pierwsza rezolucja ONZ nr 1737 została przyjęta w grudniu 2006 r. $^{25}$ Zakazano w niej dostaw technologii jądrowej do Iranu oraz nakazano zamrożenie aktywów osób i organizacji zaangażowanych w program wzbogacania uranu. W rezolucjach nr $1747 \mathrm{w} 2007^{26} \mathrm{i} \mathrm{nr} 1803 \mathrm{w} 2008 \mathrm{r}^{27}$ dodano ograniczenia majace na celu zahamowanie irańskich działań. Rezolucja RB ONZ nr 1929 z 2010 r. ${ }^{28}$ rozszerzała embargo na broń oraz ograniczenia dla przedsiębiorstw finansowych i żeglugowych związanych $\mathrm{z}$ „działaniami wrażliwymi z punktu widzenia rozprzestrzeniania materiałów jądrowych" ${ }^{29}$. RB ONZ w ten sposób karała Iran za brak postępów w realizacji wynegocjowanych postanowień. Wzmocniło to pozycję Zachodu. Podejście dyplomatyczne, promowane przez UE, nie zostało porzucone, a poparte środkami preferowanymi przez USA. Nałożone przez RB ONZ ograniczenia nie były zbyt surowe. Ich znaczenie polegało jednak na tym, że społeczność międzynarodowa, w tym wielkie mocarstwa, wyraziły dezaprobatę dla irańskiego programu jądrowego. Zachęciło to poszczególne państwa członkowskie do wprowadzenia indywidualnych, surowszych sankcji.

Inną ważną kwestia, która skłoniła UE do dostosowania się do strategii USA wobec Iranu, była intensywna kampania delegatów Departamentów Skarbu i Stanu. Rozmawiali oni z władzami europejskich przedsiębiorstw, w szczególności instytucji finansowych. Ostrzegali przed ryzykiem utrzymania działalności gospodarczej w Iranie, gdyż mogło to sprawić, że firmy te stałyby się celem amerykańskich sankcji wtórnych ${ }^{30}$. Wiele europejskich podmiotów gospodarczych uległo tej presji. Do połowy 2007 r. można było zaobserwować znaczne wycofanie

${ }^{25} \mathrm{https} / / /$ www.undocs.org/S/RES/1737\%20(2006) (21 V 2020).

${ }^{26} \mathrm{https}: / /$ www.undocs.org/S/RES/1747\%20(2007) (21 V 2020).

${ }^{27} \mathrm{https} / / / \mathrm{www} . i a e a . o r g /$ sites/default/files/unsc_res1803-2008.pdf (21 V 2020).

${ }^{28} \mathrm{https} / / /$ www.iaea.org/sites/default/files/unsc_res1929-2010.pdf (21 V 2020).

29 Security Council Imposes Additional Sanctions on Iran, Voting 12 in Favour to 2 Against, with 1 Abstention, 9 VI 2010 r., http://www.un.org/press/en/2010/sc9948. doc.htm (30 IX 2021).

${ }^{30}$ Według J.E. Meyera sankcje wtórne to „ograniczenia gospodarcze majace na celu zniechęcenie podmiotów z państw trzecich do wspierania podmiotu, na który zostały nałożone sankcje”; tenże, Second Thoughts on Secondary Sanctions, „University of Pennsylvania Journal of International Law” 30, 2009, nr 3, s. 906. Moga one „stanowić dla państw skuteczny środek wywierania wpływu na działalność zagranicznych firm i osób fizycznych działających za granica”; G.E. Shambaugh, States, Firms, and Power: Successful Sanctions in United States Foreign Policy, New York 1999, s. 161. 
się europejskich firm, banków i firm ubezpieczeniowych z Iranu. Także niektórzy przywódcy, np. kanclerz Niemiec Angela Merkel, przyjęli strategię zniechęcania rodzimych przedsiębiorstw do działalności w Iranie ${ }^{31}$. Sytuacja była podobna do tej z 1996 r., ale tym razem Europejczycy nie protestowali. Wręcz przeciwnie, wyniki amerykańskiej kampanii skłoniły UE do nałożenia jednostronnych sankcji na Iran w 2007 r. $^{32}$

Opinia EU3 miała decydujący wpływ na ostateczna politykę państw członkowskich UE wobec Iranu ${ }^{33}$. Najbardziej zdecydowana Wielka Brytania miała „specjalne stosunki” z USA, a działajacy od 2010 r. rząd Davida Camerona był przekonany o konieczności zaostrzenia sankcji. Po wygraniu przez Nicolasa Sarkozy'ego wyborów prezydenckich w 2007 r. również Francja wywierała większy nacisk na Iran. Chirac był sceptyczny w kwestii sankcji - oceniał je jako nieskuteczne. Poza tym stosunki francusko-amerykańskie nie układały się za jego prezydentury poprawnie z powodu negatywnego stosunku Francji do interwencji USA w Iraku w 2003 r. Sarkozy był bardziej aktywny w polityce zagranicznej i dążył do zbudowania bliższych relacji z USA. Twierdził, że irański program jądrowy jest kluczowym zagrożeniem dla międzynarodowego bezpieczeństwa ${ }^{34}$. Politycy francuscy zaproponowali w 2009 r. wprowadzenie przez UE zakazu inwestycji energetycznych - jednak wtedy UE nie zdecydowała się na ten krok. W Niemczech zmiana układu politycznego nastapiła w 2005 r., kiedy kanclerzem została Angela Merkel, następczyni Gerharda Schrödera, który sprzeciwiał się polityce amerykańskiej. Merkel planowała odnowienie partnerstwa transatlantyckiego. Jednak stanowisko Niemiec wobec Iranu nie było tak surowe jak Francji, gdyż Berlin był największym partnerem handlowym Teheranu w całej UE. Początkowo Niemcy preferowały dwutorowe podejście: dialog dyplomatyczny wraz z groźbą sankcji, ale w 2009 r., gdy Guido Westerwelle został ministrem spraw zagranicznych, popierały nałożenie restrykcji gospodarczych ${ }^{35}$.

${ }^{31}$ S. Lohmann, The Convergence of Transatlantic Sanction Policy Against Iran, „Cambridge Review of International Affairs” 29, 2016, nr 3, s. 938-939.

${ }^{32}$ M. Pieper, Transatlantic Dialogue on Iran. The European Subaltern and Hegemonic Constraints in the Implementation of the 2015 Nuclear Agreement with Iran, „European Security” 26, 2017, nr 1, s. 103.

${ }^{33}$ Znaczaca rola EU3 w UE jest szerzej wyjaśniona w: S. Lehne, The Big Three in EU Foreign Policy, 5 VII 2012 r., http://carnegieeurope.eu/publications/?fa=48759\# (30 IX 2021).

34 Sarkozy Says Letting Iran Go Nuclear Could Cause War, „Reuters”, 25 IX 2007, https://fr.reuters.com/article/idUSN25386641 (3 X 2020).

${ }^{35}$ R. Patterson, dz. cyt., s. 138-140. 
Przeciwne niemieckiemu rozwiąaniu były południowe państwa UE: Cypr, Grecja, Hiszpania, Portugalia i Włochy, które były bardziej zależne od irańskiej ropy naftowej. Ich opinia była jednak mniej znacząca, potrzebowały bowiem pomocy ze strony UE, zwłaszcza Niemiec, ponieważ były w dużo większym stopniu poszkodowane przez kryzys finansowy. Jednak aby uniknąć protestów innych członków UE, Francja, Niemcy i Wielka Brytania konsultowały się z nimi. Nieformalna presję wywierały też USA, które z kolei wpływały na Międzynarodowy Fundusz Walutowy.

W lipcu 2010 r. UE zobowiązywała rządy państw członkowskich do wstrzymania inwestycji $\mathrm{w}$ irański sektor surowcowy, zakazywała wsparcia dla handlu oraz ograniczyła transakcje finansowe. Wprost zniechęcała europejskie przedsiębiorstwa do angażowania się w tym państwie $^{36}$. W ten sposób sankcje europejskie stały się bardziej spójne z amerykańskimi. 24 VI 2010 r. Kongres USA przyją bowiem ustawę Comprehensive Iran Sanctions, Accountability, Divestment Act (CISADA). Znalazły się w niej zapisy o sankcjach wtórnych. Zagraniczne przedsiębiorstwa miały ograniczyć wywóz rafinowanej ropy naftowej do Iranu oraz sprzedaż sprzętu i usług, które pomogłyby Iranowi w jej produkcji lub przywozie. Ustawa zobowiązała administrację do rozpoczęcia dochodzenia, gdy tylko pojawią się wiarygodne informacje o ewentualnych naruszeniach prawa przez państwa trzecie ${ }^{37}$. Prezydent Barack Obama wprowadził też restrykcje dotyczące urzędników irańskich odpowiedzialnych za poważne naruszenia praw człowieka oraz nałożył dalsze sankcje na niektóre podmioty, zgodnie z ustawą o sankcjach wobec Iranu z 1996 r. $^{38}$

Pomimo wielu zachęt zaproponowanych przez negocjatorów europejskich, było oczywiste, że dialog dyplomatyczny nie przyniósł znaczacych postępów, mimo że Europa zintensyfikowała stosunki gospodarcze z Iranem. Jednocześnie Stany Zjednoczone nie osiagnęły głównego celu: zahamowania irańskiego programu nuklearnego, choć sankcje obowiązywały już niemal trzy dekady. Najlepszym sposobem na jego osiagnięcie była koordynacja sankcji amerykańskich i europejskich, przy jednoczesnym skłanianiu państw trzecich do ograniczania relacji gospodarczych z Iranem. UE, zauważając nieskuteczność stosowania jedynie środków

${ }^{36}$ C. Adebahr, Easing EU Sanctions on Iran, http://carnegieendowment. org/2014/06/16/easing-eu-sanctions-on-iran-pub-55955 (16 VI 2014).

37 https://www.treasury.gov/resource-center/sanctions/Programs/Documents/ CISADA_english.pdf (17 VI 2020).

38 J. Starr, H. Ighani, Timeline of U.S. Sanctions, http://iranprimer.usip.org/ resource/timeline-us-sanctions (17 VI 2020). 
dyplomatycznych, a także obawiając się ataku amerykańskiego na Iran i ulegając presji władz USA, coraz bardziej skłaniała się do takiego rozwiązania. Tym bardziej że sankcje nałożone przez RB ONZ dawały legitymizację prawną do takich działań.

\section{Przełom roku 2011}

W drugiej dekadzie XXI w. można było zaobserwować wzrost napięcia między Iranem a Zachodem na tle rozwijanego przez Teheran programu nuklearnego. Sankcje oddziaływały negatywnie na gospodarkę irańska, zwłaszcza na jej możliwości eksportowe (w 2011 r. Iran sprzedawał średnio mniej o około milion baryłek ropy dziennie niż w latach poprzednich), wartość riala spadła o niemal $40 \%$, wiele firm zachodnich wycofało się z działalności w tym państwie ${ }^{39}$. W listopadzie $2011 \mathrm{r}$. opublikowany został raport MAEA. Podkreślono w nim prawdopodobny militarny wymiar irańskiego programu jądrowego. Napięcie w stosunkach z Zachodem widać było w wydarzeniach z 29 XI 2011 r., kiedy protestujacy zaatakowali ambasadę brytyjską w Teheranie. Wiele europejskich państw potępiło wówczas irański rząd za brak ochrony zagranicznej placówki dyplomatycznej ${ }^{40}$. W listopadzie 2011 r. Wielka Brytania, a także USA i Kanada nałożyły na Iran kolejne sankcje z powodu prowadzonego programu nuklearnego. Wszystkie brytyjskie instytucje finansowe zostały zobowiązane do zaprzestania prowadzenia interesów z kontrahentami irańskimi.

Władze USA i UE zgadzały się w kwestii potrzeby zapobiegania dalszemu rozwojowi irańskiego programu nuklearnego. Ponieważ działania militarne nie były wówczas brane pod uwagę, rozmawiano na temat wspólnego planu dalszych sankcji. Spodziewano się, że problemy gospodarcze pozbawią reżim środków na program jądrowy. Przedstawiciele USA, UE, ale też Arabii Saudyjskiej, Australii, Japonii i Korei

${ }^{39}$ Fact Sheet. Sanctions Related to Iran, https://obamawhitehouse.archives.gov/ the-press-office/2012/07/31/fact-sheet-sanctions-related-iran (30 IX 2021); Central Bank of Iran, https://www.cbi.ir/simplelist/1419.aspx (30 IX 2021). Więcej na ten temat zob. P. Rivlin, Leverage of Economic Sanctions. The Case of US Sanctions Against Iran, 1979-2016, w: Geo-economics and Power Politics in the 21 ${ }^{\text {st }}$ Century. The Revival of Economic Statecraft, red. M. Wigell, S. Scholvin, M. Aaltola, London-New York 2019, s. 106-108.

${ }^{40}$ Britain Withdraws Diplomats from Iran after Embassy Attack, „The Guardian”, 30 XI 2011, https://www.theguardian.com/world/2011/nov/30/britain-withdrawsdiplomats-iran (30 IX 2021). 
Południowej spotkali się 11 XII 2011 r. w Rzymie, aby uzgodnić środki mające skłonić Iran do ponownego rozpoczęcia negocjacji. Przedstawiciele UE rozważali scenariusz, że nowy pakiet sankcji obejmie unijne embargo na ropę naftowa. USA przekonały Arabię Saudyjską do produkcji większej ilości tego surowca, aby zrekompensować Europejczykom straty i zapobiec gwałtownemu wzrostowi cen. Iran był głównym rywalem Arabii Saudyjskiej na Bliskim Wschodzie, a skoordynowane embargo zachodnie mogłoby osłabić jego gospodarkę, w dużym stopniu zależna od cen ropy ${ }^{41}$. W czasie kryzysu finansowego była to jednak bardzo trudna dla UE decyzja, ponieważ państwa europejskie (zwłaszcza z południa kontynentu) były w dużym stopniu uzależnione od irańskiej ropy. W 2011 r. UE wciąz importowała z Iranu ok. 600 tys. baryłek ropy dziennie. Wielkie europejskie firmy, takie jak Royal Dutch Shell i Total, były powiązane z Iranem obowiąującymi kontraktami i znaczacymi inwestycjami ${ }^{42}$.

Celem Waszyngtonu było przekonanie UE do przyłączenia się do wzmożonych sankcji, ponieważ to jej członkowie byli głównymi partnerami handlowymi Teheranu (zob. wykres 1). Wówczas sankcje mogłyby odnieść skutek, gdyż stosunki gospodarcze Stanów Zjednoczonych z Iranem były wręcz śladowe (zob. wykres 2). Sankcje amerykańskie, trwające

Wykres 1. Handel towarami między UE a Iranem w latach 2008-2012 (w mld EUR)

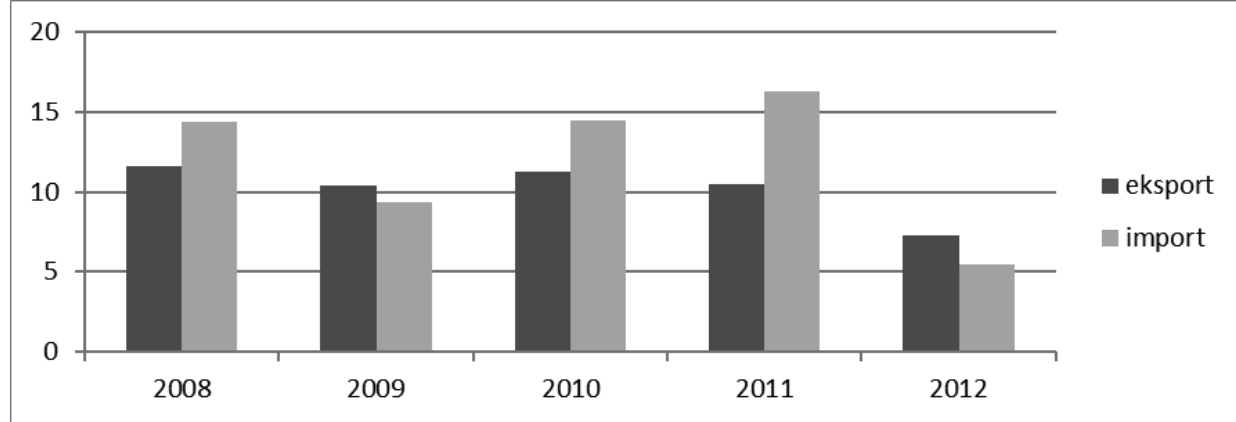

Źródło: Eurostat, http://trade.ec.europa.eu/doclib/docs/2006/september/tradoc_113392.pdf (30 IX 2021).

${ }^{41}$ T. Van de Graaf, The "Oil Weapon" Reversed? Sanctions against Iran and U.S. - EU Structural Power, „Middle East Policy” 20, 2013, nr 3, s. 155; zob. też J. Chaffin, J. Blas, J. Blitz, Europe Prepares Iran Oil Embargo, „The Financial Times”, 1 XII 2011, http:// www.ft.com/intl/cms/s/0/4d6efae2-1c44-11e1-af09-00144feabdc0.html\#axzz2UDBNbCzF (17 V 2020); R. Landucci, P. Pullella, Diplomats Agree to Increase Pressure on Iran, „Reuters”, 20 XII 2011, http://www.reuters.com/article/us-iran-sanctions-meetingidUSTRE7BJ1XJ20111220 (17 V 2020).

${ }^{42}$ Under Sanctions, Iran's Crude Oil Exports Have Nearly Halved in Three Years, 24 VI 2015 r., http://www.eia.gov/todayinenergy/detail.cfm?id=21792 (30 IX 2021). 
Wykres 2. Handel towarami między USA a Iranem w latach 2008-2012 (w mln USD)

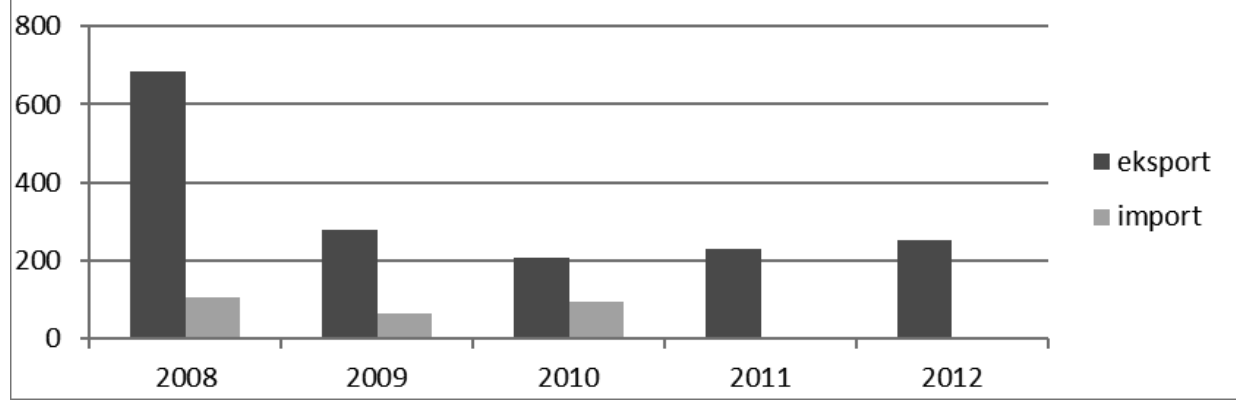

Źródło: Census Bureau, https://www.census.gov/foreign-trade/balance/c5070.html (30 IX 2021).

od wielu lat, nie uderzały już w irańska gospodarkę. Przykładem dobrze ilustrującym to zjawisko było embargo na irańską ropę naftową wprowadzone w październiku 1987 r. Wówczas nieoczekiwanie eksport irański wzrósł - Teheran znalazł nowych nabywców, a sojusznicy USA odmówili przyłączenia się do polityki amerykańskiej ${ }^{43}$.

Pomimo aktywnej roli USA w łagodzeniu negatywnych skutków dla gospodarek europejskich (choćby negocjacje z Arabią Saudyjska), w UE nie było przekonania co do konieczności zintensyfikowania sankcji. Poważne obawy zgłaszały firmy, które miały lukratywne kontrakty z Iranem. Z drugiej strony, ze względu na długotrwały i złożony system amerykańskich sankcji, trudno było określić, za które działania handlowe lub inwestycyjne firma może zostać objęta amerykańskimi sankcjami wtórnymi w ramach ustawy CISADA. Było oczywiste, że rządy państw UE, które same nałożyły sankcje, nie będą wtedy bronić interesów przedsiębiorstw. W ten sposób administracja amerykańska właściwie wymusiła stopniowe wycofywanie europejskich firm z Iranu, jeszcze przed nałożeniem wszystkich sankcji przez UE. Należy zauważyć, że po wprowadzeniu przez UE zakazu inwestycji w sektorze naftowym i gazowym od $2010 \mathrm{r}$. firmy europejskie działające w innych obszarach również stanęły przed problemem dyskryminacji w Iranie ${ }^{44}$. Ten stan rzeczy miał decydujące znaczenie dla decyzji UE o rozszerzeniu sankcji.

Poza tym USA i UE miały wspólne cele, które były priorytetem $\mathrm{w}$ ich polityce zagranicznej. Najważniejszym z nich było ograniczenie

${ }^{43}$ T. Van de Graaf, dz. cyt., s. 151-152.

${ }^{44} \mathrm{C}$. Therme, Iran and Iraq. Between Reconstruction and Containment, w: The Neighbours of the European Union's Neighbours. Diplomatic and Geopolitical Dimension Beyond the European Neighbourhood Policy, red. S. Gstöhl, E. Lannon, London 2016, s. 148. 
irańskiego programu jądrowego, a tym sama ochrona traktatu o nierozprzestrzenianiu broni nuklearnej. W Europejskiej Strategii Bezpieczeństwa z 2003 r. rozprzestrzenianie broni masowego rażenia zostało uznane za „potencjalnie największe zagrożenie dla bezpieczeństwa UE”45. Amerykanie, podobnie jak Europejczycy, planowali rozwiąać problem w drodze negocjacji dyplomatycznych, ale w przypadku ich niepowodzenia były gotowe „wykorzystać wszystkie elementy amerykańskiej władzy, aby osiagnaćc ten cel" ${ }^{46}$. Wiązało się to z kolejnym wspólnym celem: zwiększeniem bezpieczeństwa w regionie tzw. Szerszego Bliskiego Wschodu (Greater Middle East). UE chciała uniknąć wyścigu zbrojeń i złagodzić wrogość między Iranem, Izraelem i Arabią Saudyjska ${ }^{47}$. Było to zgodne z żywotnymi interesami Stanów Zjednoczonych. W Narodowej Strategii Bezpieczeństwa w 2010 r. wskazano Iran jako główne zagrożenie dla USA ${ }^{48}$. Administracja prezydenta Obamy chciała łagodzić napięcia z Teheranem. Postrzeganie USA jako głównego wroga umocniło konserwatywne i radykalne siły polityczne w Iranie. Sankcje mogłyby osłabić irański reżim, a poprawa relacji po zawarciu ewentualnego porozumienia nuklearnego mogłoby zwiększyć znaczenie bardziej liberalnych sił. Przede wszystkim Stany Zjednoczone chciały poprawić bezpieczeństwo głównych sojuszników: Izraela i Arabii Saudyjskiej. Miały one również na celu ograniczenie ambicji Teheranu do poszerzenia jego wpływów w regionie. Wsparcie Iranu dla Baszara al-Assada w Syrii oraz zaangażowanie w wojnę domową w Jemenie były postrzegane jako zagrożenie stabilności regionu. Priorytetem było także powstrzymanie Iranu od aktywnego wspierania organizacji terrorystycznych, np. Hezbollahu czy Hamasu ${ }^{49}$. Zarówno USA, jak i UE wprowadziły również sankcje dotyczące łamania przez irański reżim praw człowieka ${ }^{50}$. W tym

${ }^{45}$ European Security Strategy. A Secure Europe in a Better World, 12 XII 2003 r., https://europa.eu/globalstrategy/en/european-security-strategy-secure-europe-betterworld (24 IX 2020).

${ }^{46}$ US Policy Towards Iran, Testimony of Wendy Sherman, Under Secretary for Political Affairs, Written Statement before the Senate Foreign Relations Committee. U.S. Department of State, 15 V 2013 r., https://2009-2017.state.gov/p/us/rm/2013/202684. html (24 IX 2020).

${ }^{47}$ F. Halliday, Iran's Regional and Strategic Interests, „Chaillot Papers” 89, 2006: Iranian Challenges, red. W. Posch, s. 59-71, https://www.iss.europa.eu/sites/default/ files/EUISSFiles/cp089.pdf (30 IX 2021)..

${ }^{48}$ National Security Strategy, 27 V 2010 r., http//nssarchive.us/national-securitystrategy-2010/ (24 IX 2020).

49 US Policy Towards Iran...

${ }^{50}$ Executive Order 13553, 28 IX 2010 r., https://www.federalregister.gov/documents/2010/10/01/2010-24839/blocking-property-of-certain-persons-with-respect-to- 
przypadku liczono na procesy liberalizacji reżimu. Stany Zjednoczone nie stawiały sobie natomiast ważnego dla UE celu: przywrócenia relacji gospodarczych z Iranem. Kwestia ta stanowiła istotną rozbieżność między sojusznikami.

Jednak od końca 2011 r. można było obserwować koordynację sankcji między USA a UE. Stany Zjednoczone wprowadziły trzy dokumenty zawierające precyzyjne określenie zakresu sankcji wobec Iranu: National Defense Authorization Act (NDAA) na 2012 r. (podpisany 31 XII 2011 r. $)^{51}$, Iran Threat Reduction and Syria Human Rights Act z 2012 r. (podpisany 10 VIII 2012 r.) $)^{52}$ oraz NDAA na 2013 r. (podpisany 2 I 2013 r.) ${ }^{53}$. Iran został odcięty od międzynarodowego systemu bankowego, a irańskie banki (w tym centralny) i instytucje finansowe zostały uznane za odpowiedzialne za pranie brudnych pieniędzy. Sankcje dotyczyły także irańskiego przemysłu petrochemicznego i infrastruktury transportowej. Zmusiły one również państwa trzecie do ograniczenia zakupów irańskiej ropy ${ }^{54}$.

UE zdecydowała się w 2012 r. nałożyć na Iran kolejne sankcje. Wprowadzone je na mocy rozporządzenia Rady Europejskiej z 23 III 2012 r. ${ }^{55}$ Dotyczyły one irańskich usług transportowych i stoczniowych, technologii związanych z ropa naftową i gazem oraz inwestycji w przemysł petrochemiczny. Podobnie jak w przypadku sankcji amerykańskich, odcięły one Iran od międzynarodowego systemu informacji bankowej SWIFT. UE postanowiła także nałożyć embargo na irańską ropę naftową i gaz ziemny (w $2011 \mathrm{r}$. stanowiły one 18\% całkowitego irańskiego eksportu $)^{56}$, na sprzęt i technologie petrochemiczne oraz na inwestycje

serious-human-rights-abuses-by-the-government (30 IX 2021); Council Regulation (EU) No 359/2011, 12 IV 2011 r., https://eur-lex.europa.eu/legal-content/EN/TXT/?qid=1512 995756086\&uri=CELEX:02011R0359-20170413 (30 IX 2021).

${ }^{51} \mathrm{https} / / / \mathrm{www} . c o n g r e s s . g o v /$ bill/112th-congress/house-bill/1540/text (30 IX 2021); zob. komentarz prawniczy do tego dokumentu: J.R. Hayes, E.J. Krauland, M. Rathbone, New Iran Sanctions Threaten Foreign Banks' Access to the United States, Impose Strict Measures on Financial System of Iran, https://www.steptoe.com/en/news-publications/ new-iran-sanctions-threaten-foreign-banks-access-to-the-united-states-impose-strictmeasures-on-financial-system-of-iran.html (30 IX 2021).

${ }^{52} \mathrm{https} / / /$ www.congress.gov/bill/112th-congress/house-bill/1905 (30 IX 2021).

${ }^{53}$ https://www.congress.gov/112/plaws/publ239/PLAW-112publ239.pdf (30 IX 2021).

${ }_{54}$ A.H. Cordesman, B. Gold, C. Coughlin-Schulte, Iran. Sanctions, Energy, Arms Control, and Regime Change, „Center for Strategic \& International Studies” 2014, s. 2, https://www.csis.org/analysis/iran-sanctions-energy-arms-control-and-regime-change (30 IX 2021).

${ }^{55}$ https://eur-lex.europa.eu/LexUriServ/LexUriServ.do?uri=OJ:L:2012:088:0001:01 12:EN:PDF (30 IX 2021).

${ }^{56} \mathrm{https}: / /$ www.eia.gov/todayinenergy/detail.php?id=14111 (30 IX 2021). 
finansowe w tym sektorze. Europejskie aktywa Centralnego Banku Iranu (CBI) zostały zamrożone, zakazano także handlu złotem i innymi cennymi materiałami między Europa a CBI. Wprowadzono zakazy podróżowania dla przedstawicieli 490 podmiotów i 150 osób powiązanych $\mathrm{z}$ irańskim programem jądrowym ${ }^{57}$. Wspólne restrykcje europejskie i amerykańskie wzmocniły siłę oddziaływania sankcji - były one bardziej dotkliwe dla Iranu ${ }^{58}$.

\section{Reakcje na sankcje Zachodu głównych partnerów handlowych Iranu}

Najbardziej widocznym skutkiem gospodarczym sankcji nałożonych na Iran był spadek inwestycji w sektorze energetycznym. W latach 2006-2009 ich średnia roczna wartość wynosiła 20 mld USD, a w latach 2010-2011 - już mniej niż 3 mld USD. Ze względu na izolację spowodowana sankcjami Iran nie mógł utrzymać produkcji ropy naftowej na tym samym poziomie i zwiększyć wydobycia gazu ziemnego. Przyciagnięcie nowych inwestorów było trudniejsze niż zwiększenie sprzedaży ${ }^{59}$. Poza tym dochody z produkcji i eksportu ropy spadły z ponad 72 mld USD w 2010 do 18 mld w 2015 r., a PKB Iranu skurczył się, osiagając w 2012 r. wartość ujemną $(-6,6 \%)^{60}$.

Mandat RB ONZ, jak również wspólne działania USA i UE wymuszały na głównych partnerach handlowych Iranu ograniczanie z nim stosunków gospodarczych. Jednak państwa takie jak Chiny i Indie nie miały zamiaru rezygnować z importu irańskiej ropy naftowej. Miało to negatywny wpływ na skuteczność sankcji, jednak i tak irański eksport surowców zmniejszył się prawie o połowę, wymuszając na Teheranie obniżanie cen. Ze względu na spadek produkcji zmniejszała się też ilość baryłek kupowanych przez wiodących importerów (zob. tab. 1).

Mimo że Chiny musiały zaakceptować sankcje nałożone przez RB ONZ, handel z Iranem został zintensyfikowany. Chiny wykorzystały wycofanie się państw UE z tego rynku, stając się największym partnerem handlowym Teheranu. Podpisane zostały nowe kontrakty na eksploatację

${ }^{57}$ C. Adebahr, Easing EU Sanctions on Iran...

${ }^{58}$ S. de Galbert, dz. cyt.

${ }^{59}$ G.C. Hufbauer, J.J. Schott, K.A. Elliott, J. Muir, M. Cosic, Case Studies in Economic Sanctions and Terrorism, Case 84-1 US v. Iran (1984-2005: Terrorism, Proliferation), Case 2006-1 UN, US [EU] v. Iran (2006: Proliferation), http://www.piie. com/publications/papers/sanctions-iran-84-1_2006-1.pdf (30 IX 2021).

${ }^{60}$ P. Rivlin, dz. cyt., s. 108-109. 
Tabela 1. Import ropy naftowej z Iranu w 2011 i 2016 r. według International Energy Agency (średnia ilość baryłek dziennie)

\begin{tabular}{|l|c|c|}
\hline \multicolumn{1}{|c|}{ Państwa/instytucje } & $\mathbf{2 0 1 1}$ & $\mathbf{2 0 1 6}$ \\
\hline UE (głównie Włochy, Hiszpania, Grecja) & 600 tys. & znikoma \\
\hline Chiny & 550 tys. & 410 tys. \\
\hline Japonia & 325 tys. & 190 tys. \\
\hline Indie & 320 tys. & 190 tys. \\
\hline Korea Południowa & 230 tys. & 130 tys. \\
\hline Turcja & 200 tys. & 120 tys. \\
\hline RPA & 80 tys. & znikoma \\
\hline Malezja & 55 tys. & znikoma \\
\hline Sri Lanka & 35 tys. & znikoma \\
\hline Tajwan & 35 tys. & 10 tys. \\
\hline Singapur & 20 tys. & 15 tys. \\
\hline Pozostałe & 55 tys. & znikoma \\
\hline Razem & 2,5 mln & 1,05 mln \\
\hline
\end{tabular}

Źródło: K. Katzman, Iran Sanctions, Congressional Research Service, 12 I 2016 r., https://www.everycrsreport.com/files/20160112_RS20871_92fd8451a2990952927d8b01db812325fc11c950.pdf (30 IX 2021).

zasobów energetycznych. Chiny ograniczyły jednak zakupy ropy, aby uniknąc amerykańskich sankcji ${ }^{61}$. Indie zrobiły to samo, ale ze względu na bardzo silne więzi polityczne, gospodarcze i kulturowe nie przyłączyły się do sankcji zachodnich. Jednak wielu przedsiębiorców postrzegało Iran jako niestabilny rynek, więc niechętnie rozwijali tam działalność. Kontakty finansowe również zostały ograniczone - Bank Rezerw Indii zaprzestał transakcji za pośrednictwem Azjatyckiej Unii Rozliczeniowej $\mathrm{z}$ siedzibą w Teheranie ${ }^{62}$.

Japonia odroczyła udzielanie kredytów i gwarancji finansowych na handel z Iranem. Stopniowo zamrażała aktywa wielu instytucji, osób prywatnych i banków, które mogły być związane z irańskim programem jądrowym. Jednak ze względu na ogromne zapotrzebowanie na energię

${ }^{61}$ Wszystkie dane uwzględniające głównych partnerów handlowych Iranu sa podane za: N.A. Kozhanov, U.S. Economic Sanctions against Iran. Undermined by External Factors, „Middle East Policy Council” 18, 2011, nr 3, s. 144-160, http://www.mepc.org/ journal/middle-east-policy-archives/us-economic-sanctions-against-iran-underminedexternal-factors?print (25 VII 2014); http://trade.ec.europa.eu/doclib/docs/2006/september/ tradoc_113392.pdf (21 IX 2014).

${ }^{62}$ K. Katzman, Iran Sanctions, Congressional Research Service, 19 VIII 2014 r., http://fas.org/sgp/crs/ mideast/RS20871.pdf (30 IX 2021). 
nadal kupowała od Iranu znaczne ilości ropy. Spadła jednak z trzeciej na siódma pozycję jako partner handlowy Iranu ${ }^{63}$.

Korea Południowa wprowadziła podobne jak UE sankcje finansowe na rozwój sektora energetycznego. Od 1 VII 2012 r. import ropy z Iranu został wstrzymany, po tym jak UE zakazała ubezpieczeń transportowych. Po dwóch miesiącach Korea Południowa wznowiła jednak zakupy, które w lutym 2014 r. były o ponad 100\% wyższe niż rok wcześniej. Seul ogłosił, że kontrakty w tych branżach, które nie są bezpośrednio powiazane z programem jądrowym, zostaną utrzymane w mocy ${ }^{64}$.

Zjednoczone Emiraty Arabskie, oprócz poparcia dla sankcji ONZ, wprowadziły dodatkowe ograniczenia. Jako wiodacy eksporter ropy naftowej, wraz z Arabią Saudyjska, zgodziły się na zwiększenie produkcji, ułatwiając tym samym państwom europejskim podjęcie decyzji o nałożeniu embarga. Z drugiej strony, pod naciskiem rodzimych przedsiębiorców i lobby irańskiego, nie wprowadziły ograniczeń w handlu. Dlatego też stały się drugim co do wielkości partnerem handlowym Iranu (w 2010 r. były na piątej pozycji).

Jeśli chodzi o pozostałe państwa G20, dodatkowe sankcje na Iran wprowadziły Australia, Kanada i RPA. W sumie więc 12 członków G20, w różnym stopniu, poparło sankcje zachodnie, a $8 \mathrm{z}$ nich wykorzystało tę sytuację do zacieśnienia kontaktów z Teheranem. Ale nawet ci „czarni rycerze”65 musieli wziać pod uwagę groźbę kar za nieprzestrzeganie zakazów amerykańskich. W ten sposób skoordynowane działania transatlantyckie były w dużym stopniu skuteczne. Główni partnerzy handlowi Iranu, jak również inne wiodące gospodarki, musiały liczyć się z polityką Zachodu, prowadząc relacje gospodarcze a Iranem. Państwa te rozważały przede wszystkim paragraf 1245 ustawy NDAA z 2012 r., który utrudniał zagranicznym bankom (mającym kontakt z irańskim reżimem) otwieranie rachunków w USA, chyba że ich państwa macierzyste uzyskałyby zwolnienie z tego zapisu poprzez znaczne ograniczenie zakupów irańskiej ropy ${ }^{66}$.

${ }^{63}$ Y. Koh, Japan Imposes New Iran Sanctions, „The Wall Street Journal”, 8 XII 2011, http://online.wsj. com/news/articles/SB1000142405297020350130457708718325 3856636 (12 V 2020).

${ }^{64}$ I.J. Chang, The Iran Sanctions and South Korea's Balancing Act, 2 VI 2014 r., http://www.mei.edu/content/map/iran-sanctions-and-south-korea\%E2\%80\%99s-balancing-act (30 IX 2021).

${ }^{65}$ Black knights - „czarni rycerze” to państwa lub firmy wykorzystujące wycofanie się głównych partnerów handlowych z danego rynku w reżimie sankcji gospodarczych do zwiększenia kontaktów z państwem podlegającym sankcjom; N.A. Kozhanov, dz. cyt.

${ }^{66}$ K. Katzman, Iran Sanctions, Congressional Research Service, 23 III 2016 r., https://www.fas.org/sgp/ crs/mideast/RL32048.pdf (30 IX 2021). 
Sankcje poważnie osłabiały gospodarkę Iranu. Znacznie spadła produkcja irańskiej ropy (ze średnio $2,5 \mathrm{mln}$ baryłek dziennie w 2011 r. do miliona na koniec 2012 r.). Sankcje finansowe odcięły Iranowi dostęp do dochodów ze sprzedaży surowców energetycznych. Drastycznie spadła również wartość riala - o ok. 80\% w stosunku do USD. Bezpośrednim skutkiem sankcji był poważny kryzys gospodarki irańskiej: produkcja przemysłowa spadła o $40 \%$, stopa bezrobocia wzrosła o blisko $40 \%$, a ceny podstawowych towarów podniosły się o ponad $100 \%{ }^{67}$.

\section{Koncepcja i realizacja Wspólnego Kompleksowego Planu Działania (JCPOA)}

Zgodnie z podejściem dwutorowym (sankcje połączone z jednoczesnym dialogiem z Iranem) grupa P5+1 próbowała wypracować kompleksowe porozumienie z Teheranem. Taki sposób postępowania był pomysłem europejskim. Jednak to transatlantycka współpraca w zakresie międzynarodowego egzekwowania sankcji umożliwiła jego realizację. Nie można w tym przypadku pominąć roli powstałej w 2011 r. unijnej Służby Działań Zewnętrznych (EAS - External Action Service), która pomogła wyeliminować rozbieżności w zakresie sankcji wobec Iranu między członkami UE. Dzięki temu pozycja negocjacyjna UE zdecydowanie wzrosła. Instytucja była też skuteczna w kontaktach $\mathrm{z}$ irańskimi dyplomatami i podczas prowadzenia rozmów w ramach $\mathrm{P} 5+1^{68}$.

Wybór w czerwcu 2013 r. na prezydenta Iranu Hassana Rouhaniego, postrzeganego jako umiarkowanego reformatora, stworzył więcej możliwości osiagnięcia kompromisu. W następstwie tymczasowego porozumienia w Genewie w listopadzie 2013 r. udało się doprowadzić do zawieszenia sankcji i przyspieszenia rozmów w sprawie końcowej umowy.

W czasie negocjacji pojawiały się jednak rozbieżności między Francja a USA. Amerykanie naciskali, aby zakończyć negocjacje do końca marca 2015 r. Francuscy dyplomaci przekonywali, że postanowienia porozumienia nie były na tyle precyzyjne, aby uniemożliwić Iranowi rozwój jego militarnego programu jądrowego. Francja postrzegała ten program jako główne zagrożenie dla regionu i była zdeterminowana, by uzyskać optymalne warunki porozumienia, bez ustalania daty

67 Tenże, Iran Sanctions, Congressional Research Service, 31 V 2013 r., http://www. fas.org/sgp/crs/mideast/RS20871.pdf (30 IX 2021).

${ }^{68}$ C. Adebahr, Europe and Iran. The Nuclear Deal and Beyond, London-New York 2017, s. $118-130$. 
zakończenia rozmów. Jeden z francuskich dyplomatów stwierdził: „Spędziliśmy ponad 10 lat na rozmowach, powoli ustalajac plan i określając zasady negocjacji. Kiedy z tego zrezygnujemy, to już nie wróci. Więc lepiej zawrzyjmy najlepsza możliwą umowe"69. Joseph Bahout i Benjamin Haddad twierdzili, że wynikało to również z faktu, iż Francja czuła się zmarginalizowana, ponieważ odbyły się oddzielne spotkania amerykańsko-irańskie. Dyplomaci twierdzili, że Amerykanie chca uzyskać gwarancje współpracy Teheranu na Bliskim Wschodzie, zwłaszcza $\mathrm{w}$ walce z Islamic State of Iraq and Syria (ISIS) w Syrii ${ }^{70}$. Ostatecznie porozumienie nie zostało podpisane i negocjacje przedłużono. Potwierdza to duży wpływ państw UE na proces dyplomatyczny. Przedstawiciele administracji amerykańskiej chcieli osiagnać porozumienie jeszcze w trakcie kadencji Baracka Obamy, ze względu na niechęć amerykańskiego Kongresu i krytykę porozumienia przez kandydatów na prezydenta, zarówno Donalda Trumpa, jak i Hilary Clinton ${ }^{71}$. Europejczycy dążyli do zawarcia ostatecznego porozumienia, które gwarantowałoby, że nie będą musieli ponownie nakładać sankcji, niekorzystnie wpływajacych także na ich gospodarki.

Przedłużone rozmowy przyniosły konkretne rezultaty. 14 VII 2015 r. P5+1, Iran oraz wysoki przedstawiciel UE ds. zagranicznych i polityki bezpieczeństwa podpisali Wspólny Kompleksowy Plan Działania (Joint Comprehensive Plan of Action - JCPOA). Iran zgodził się zmniejszyć o 2/3 liczbę wirówek, nie wzbogacać uranu w ciagu 15 lat oraz zmniejszyć jego istniejace zapasy. MAEA miała mieć regularny dostęp do wszystkich irańskich obiektów jądrowych, aby kontrolować wypełnianie tego porozumienia. JCPOA zawierał klauzulę, że sankcje USA i UE związane z programem jądrowym zostaną zniesione, jak również te nałożone na podstawie rezolucji RB ONZ. Podkreślono jednak, że w ramach porozumienia nadal będa obowiązywały amerykańskie sankcje wobec Iranu za wspieranie organizacji terrorystycznych, łamanie praw człowieka i próby z rakietami balistycznymi ${ }^{72}$.

Przed wdrożeniem porozumienia (po wypełnieniu jego postanowień przez Iran) ONZ, UE i USA koordynowały prace w celu zniesienia

${ }^{69}$ Cyt. za: J. Bahout, B. Haddad, How France Became an Iran Hawk, 30 III 2015 r., http://carnegieendowment.org/2015/03/30/how-france-became-iran-hawk/i56y (30 IX 2021).

70 Tamże.

${ }^{71}$ S. Lohmann, dz. cyt., s. 942.

${ }^{72}$ Joint Comprehensive Plan of Action, Vienna, 14 VII 2015, http://eeas.europa.eu/ statements-eeas/docs/iran_agreement/iran_joint-comprehensive-plan-of-action_en.pdf (30 IX 2021). 
sankcji. Transatlantycka Rada Biznesu (TABC) wraz z Amerykańską Izbą Handlowa dla UE (AmCham EU) zorganizowały w tym celu „okragły stół”. Wytyczne weszły w życie 16 I 2016 r. po akceptacji MAEA, która potwierdziła, że Iran wdrożył wszystkie wymagane środki ${ }^{73}$. Proces znoszenia sankcji mógł się rozpocząć. Prezydent Obama podpisał rozporządzenie wykonawcze uchylające sankcje wobec Iranu związane z programem nuklearnym, uznając, że Iran wypełnia zobowiązania zawarte w JCPOA ${ }^{74}$. Także UE i RB ONZ wycofały się z większości sankcji ${ }^{75}$.

Proces synchronizacji znoszenia sankcji był kluczowy dla pełnego wdrożenia JCPOA. Było to trudne, ponieważ zdominowany przez republikanów Kongres był niechętny ich anulowaniu. W styczniu 2015 r. brytyjski premier Cameron podczas wizyty w Waszyngtonie przekonywał kongresmenów, że utrzymywanie i rozszerzanie sankcji jest bezcelowe. Europejscy przywódcy obawiali się, że umowa może zostać zablokowana $^{76}$. Wiele firm europejskich, które planowały otwarcie lub wznowienie działalności w Iranie, była bowiem również obecna na rynku amerykańskim. Dlatego potrzebne były im zapewnienia, że nie stana się przedmiotem amerykańskich sankcji. Można było zaobserwować odmienne podejście do normalizacji stosunków gospodarczych z Iranem, co powodowało rozbieżności między UE a USA.

Irańczycy byli rozczarowani powolnym tempem odzyskiwania stabilizacji i oczekiwali szybszych inwestycji oraz działań wspierających prowadzenie działalności gospodarczej ${ }^{77}$. W kwietniu 2016 r. Iran zwrócił się do UE o wywarcie nacisku na USA, aby uzyskać możliwość ponownego wejścia do światowego systemu finansowego. Wysoka przedstawiciel

${ }^{73}$ E. Geranmayeh, Iran Deal Implementation Day. How it Works, 18 I 2016 r., http:// www.ecfr.eu/article/commentary_implementation_day_an_explainer5064 (29 X 2020).

${ }^{74}$ D.E. Rennack, Iran. U.S. Economic Sanctions and the Authority to Lift Restrictions, https://fas.org/sgp/crs/mideast/R43311.pdf (30 IX 2021).

${ }^{75}$ UE zniosła embargo na ropę i gaz, sankcje na transakcje finansowe i bankowe, usunęła niektóre (ale nie wszystkie) osoby i podmioty z listy objętych sankcjami. Embargo na broń i ograniczenia dotyczące transferu rakiet balistycznych pozostały w mocy przez 8 lat. Sankcje RB ONZ na broń konwencjonalna, która była związana z działalnością jądrową Iranu, pozostała w mocy przez 5 lat, natomiast sankcje na irański program rakietowy zwiąany z działalnością jądrową wygasną za 8 lat; The Timing / Guidelines Was Agreed. Trans-Atlantic Business Council Roundtable Discussion. U.S.-EU Cooperation on Sanctions in the JCPOA Agreement with Iran and the U.S. and EU Sanctions Guidelines, 1 III 2016 r., http://www.transatlanticbusiness.org/events/ roundtable-discussion-u-s-eu-cooperation-on-sanctions-in-the-jcpoa-agreement-withiran-and-the-u-s-and-eu-sanctions-guidelines (23 VIII 2021).

${ }^{76}$ G. Martin, dz. cyt.

77 C. Adebahr, Easing EU Sanctions on Iran... 
UE ds. zagranicznych i polityki bezpieczeństwa Federica Mogherini oczekiwała od Waszyngtonu zapewnien, że europejskie banki sa w stanie legalnie działać w Iranie. Banki amerykańskie nadal bowiem obowiązywał zakaz prowadzenia takiej działalności, ponieważ Waszyngton oskarżał Teheran o wspieranie organizacji terrorystycznych i naruszanie praw człowieka. Banki europejskie były wcześniej obłożone karami amerykańskimi za łamanie reżimu sankcji, dlatego też obawiały się ponownego wejścia do Iranu. Amerykanie konsekwentnie odmawiali Iranowi dostępu do swojego systemu finansowego. Chociaż amerykański sekretarz stanu John Kerry stwierdził, że zagraniczne banki moga tam działać ${ }^{78}$, to wątpliwości pozostawały. Główne obawy związane były z utrzymywanym przez USA zakazem handlu dolarowego z Iranem. Kerry zachęcał banki do pozyskiwania w każdym przypadku aktualnych informacji z Departamentu Skarbu, co tylko pokazywało, że zasady nie były jasne. Firmy europejskie rozpoczęły jednak starania o wejście na rynek irański (np. francuskie przedsiębiorstwa planowały na nim inwestycje na ponad $30 \mathrm{mld}$ USD), ale nie dostały gwarancji kredytowych na działalność 79 .

Mogherini odwiedziła Teheran w kwietniu 2016 r. Po spotkaniu z nią irański minister spraw zagranicznych Mohamad Dżawad Zarif stwierdził, że obie strony będą działać na rzecz zmiany amerykańskiego nastawienia ${ }^{80}$. Mogherini potwierdziła plany odnowienia stosunków z Iranem. Przywrócenie importu surowców energetycznych było szczególnie ważne, ponieważ UE starała się zbudować wspólną politykę energetyczną i zmniejszyć zależność od dostaw z Rosji. Mogherini deklarowała ponadto poparcie dla członkostwa Iranu w Światowej Organizacji Handlu $^{81}$. Dostrzegała wagę współpracy z Iranem w celu zwiększenia stabilności na Bliskim Wschodzie. Dlatego zapowiadała: „Będziemy dyskutować o tym, jak rozwiązać wiele regionalnych kryzysów dręczących Bliski Wschód, jak najlepiej walczyć z terrorystami z ISIS, jak

78 Iran's Supreme Leader Says U.S. Lifted Sanctions Only on Paper, „Reuters”, 27 IV 2016, http://www.reuters.com/article/us-iran-economy-khamenei-idUSKCNOXOORK (20 VI 2021).

${ }^{79}$ F. Benedetti, V.L. Nasseri, Europe’s Banks Are Staying Out of Iran, „Bloomberg”, 2 V 2016, http://www.bloomberg.com/news/articles/2016-05-03/europe-s-banks-hauntedby-u-s-fines-forgo-iran-deals-amid-boom (20 VI 2021).

${ }^{80}$ Grounds Laid for Iran, EU Structured Cooperation: Mogherini, 18 IV 2016 r., http://theiranproject.com/blog/2016/04/18/grounds-laid-iran-eu-structured-cooperationmogherini (30 IX 2021).

${ }^{81}$ Iran Seeks EU Leverage to Get Financial Concessions from U.S., „Reuters”, 17 IV 2016, http://www.reuters.com/article/us-iran-nuclear-usa-idUSKCN0XD0E3 (20 VI 2021). 
ustabilizować sytuację w Afganistanie"82. Równocześnie krytykowała otwarcie Iran za przeprowadzenie testów rakiet balistycznych. Od momentu uzgodnienia JCPOA Iran przeprowadził trzy testy (w październiku i listopadzie 2015 oraz w marcu 2016 r.). USA odpowiedziały na nie nowym zestawem sankcji, skierowanym na odpowiedzialne podmioty i osoby. Mogherini podkreśliła jednak, że nie można irańskich testów uznać za naruszenie $\mathrm{JCPOA}^{83}$.

Istniała groźba, że rozbieżności w sprawie działań Iranu podzielą sojusz transatlantycki. Europejczycy twierdzili, że strategia USA polegająca na utrzymaniu części ograniczeń nie tylko zagrażała ich planom biznesowym, ale także powodowała rosnące rozczarowanie w Iranie. Maria Renske Schaake, wiceprzewodnicząca delegacji Parlamentu Europejskiego ds. stosunków z USA, stwierdziła nawet: „Europa staje się zakładnikiem polityki amerykańskiej. Wspólnie negocjowaliśmy umowę dotycząca broni jądrowej, ale teraz Stany Zjednoczone utrudniaja jej wykonanie" ${ }^{44}$. Warto zauważyć, że paradoksalnie polityka amerykańska mogłaby wzmocnić irańskich konserwatystów i osłabić pozycję prezydenta Rouhaniego. Oprócz blokady działalności instytucji finansowych USA nie uwolniły również wszystkich aktywów irańskich (tylko 3 mld z zapowiadanych 150 mld USD zostały zwrócone), oskarżając Iran o wspieranie organizacji terrorystycznych i pranie brudnych pieniędzy ${ }^{85}$. Realizacja JCPOA wydawała się trudniejsza niż jej przygotowanie.

\section{Konsekwencje polityki Donalda Trumpa wobec Iranu}

Problemy europejskich przedsiębiorców z dostosowaniem się do amerykańskich sankcji wobec Iranu (po podpisaniu JCPOA) nie były przejściowe. Donald Trump, który przejął władzę 20 I 2017 r., kwestionował porozumienie, nazywał je katastrofalnym i zapowiadał jego renegocjację. Mimo pozytywnej opinii MAEA i pozostałych sygnatariuszy JCPOA, w październiku 2017 r. Trump uznał, że Iran nie wypełnia warunków w nim zawartych. Nie brał pod uwagę opinii MAEA, która

${ }^{82}$ Grounds Laid for Iran...

${ }^{83}$ Iran Seeks EU Leverage...

${ }^{84}$ T. Erdbrink, Europe Says U.S. Regulations Keeping It From Trade With Iran, „The New York Times", 21 IV 2016, http://www.nytimes.com/2016/04/22/world/middleeast/ europe-says-us-regulations-keeping-it-from-trade-with-iran.html (17 VI 2021).

${ }_{85}$ Tamże. 
pozytywnie zweryfikowała realizację porozumienia przez $\operatorname{Iran}^{86}$. UE namawiała USA do zmiany stanowiska. Mimo intensywnych europejskich działań dyplomatycznych, w maju 2018 r. Trump ogłosił wycofanie się USA z JCPOA oraz przywrócenie wszystkich obowiązujących wcześniej sankcji, nakładając je również na firmy prowadzące interesy z Iranem ${ }^{87}$.

Decyzja Trumpa oznaczała rozejście się wspólnej transatlantyckiej polityki wobec Iranu. UE deklarowała bowiem przywiazanie do postanowień JCPOA. Europejskie firmy obawiając się sankcji ze strony USA, zaczęły wycofywać się z Iranu. Duże europejskie korporacje, np. Airbus, Deutsche Bank czy Total, rezygnowały z kontraktów. Transakcje międzynarodowe były prowadzone $\mathrm{w}$ dolarach amerykańskich, a administracja USA obłożyła sankcjami przedsiębiorstwa, które rozliczały się w tej walucie. Przeszkodą dla prowadzenia relacji gospodarczych z Iranem było odłączenie wielu instytucji finansowych tego państwa od systemu SWIFT (z siedziba w Belgii), co utrudniało transakcje. Decyzja została podjęta pod presją USA, które zagroziły, że w innym przypadku restrykcje zostana nałożone na SWIFT. 31 I 2019 r. Francja, Niemcy i Wielka Brytania ogłosiły uruchomienie Instrumentu Wspierania Wymiany Handlowej (INSTEX). Otwiera on kanał handlowy dla europejskich banków i dla biznesu z Iranem, który został zagrożony sankcjami USA. Dzięki temu handel między UE a Iranem miał się odbywać poza bazującym na dolarze systemem SWIFT. INSTEX mógł być wykorzystywany głównie przez małe i średnie przedsiębiorstwa, które nie miały powiązań z rynkiem amerykańskim. Jednak nie miał szerokiego zastosowania, po raz pierwszy użyto go w kwietniu 2020 r., by ułatwić wysłanie sprzętu medycznego koniecznego do walki z epidemią COVID-1988. Decyzja Trumpa uderzyła jednak przede wszystkim w Iran, który planował znacznie zwiększyć produkcję i sprzedaż ropy oraz otworzyć się na zachodnie inwestycje. Plany te zostały pokrzyżowane, co sprawiało, że bardzo mało prawdopodobny był powrót do poziomów eksploatacji strategicznego surowca sprzed sankcji nakładanych od 2012 r. $^{89}$

${ }^{86}$ Verification and Monitoring in the Islamic Republic of Iran in Light of United Nations Security Council Resolution 2231 (2015), https://www.iaea.org/sites/default/ files/16/06/gov2016-23.pdf (30 IX 2021).

${ }^{87}$ Więcej zob. P. Matera, R. Matera, Why Does Cooperation Work or Fail? The Case of EU-US Sanction Policy Against Iran, „Croatian International Relations Review” 25 (85), 2019, s. 47-49.

88 A. Brzozowski, EU's INSTEX mechanism facilitates first transaction with pandemic-hit Iran, „Euractiv”, 31 III 2020, https://www.euractiv.com/section/globaleurope/news/eus-instex-mechanism-facilitates-first-transaction-with-pandemic-hit-iran/ (30 IX 2021).

${ }^{89}$ L. Rosenberger, Economic Statecraft and US Foreign Policy, London 2020, s. 81. 
Wspólna zachodnia polityka sankcji uległa jeszcze większemu rozchwianiu po wydarzeniach ze stycznia 2020 r., kiedy najpierw w wyniku ataku amerykańskiego drona zginął irański dowódca wojskowy gen. Kasem Sulejmani ${ }^{90}$, a następnie Iran wystrzelił rakiety w bazy amerykańskie w Iraku. Spowodowało to poważny kryzys na Bliskim Wschodzie. Już w pierwszym wystapieniu po ataku irańskim, 8 I 2020 r., Trump wezwał NATO do większej aktywności na rzecz stabilności regionalnej, ale też zaapelował do mocarstw o wypracowanie porozumienia z Teheranem. Prezydent oznajmił, że „USA nałożą natychmiastowe dodatkowe karne sankcje gospodarcze na irański reżim”. Dodał, że „potężne sankcje zostana utrzymane do czasu, gdy Iran zmieni postępowanie, zarzuci ambicje nuklearne i zaprzestanie wspierania terrorystów"91. Trudno przewidywać, by w tak dramatycznych okolicznościach można było szybko powrócić do wspólnej polityki sankcji osłabiającej irański reżim, mającej przecież na celu stabilizację w regionie. Warto również zaznaczyć, że sankcje wobec Iranu złagodziła ONZ. Mimo nacisków USA, Rada Bezpieczeństwa nie przedłużyła embarga ONZ na dostawy broni konwencjonalnej dla Iranu, które wygasło 18 X 2020 r. ${ }^{92}$

\section{Konkluzje}

Stany Zjednoczone od 40 lat utrzymywały sankcje wobec irańskiego reżimu. Słusznie uznawane były za głównego inicjatora i menedżera restrykcji wobec Teheranu. Faktyczne włączenie państw europejskich do polityki sankcji nastapiło dopiero wraz z rezolucja RB ONZ w 2006 r., a odrębne restrykcje europejskie uruchomiono od 2012 r. Wśród państw UE znajdowali się bowiem główni partnerzy handlowi Iranu. Jednak korzyści z członkostwa w UE przekonały niechętne sankcjom państwa do ich akceptacji ${ }^{33}$. Mogły one liczyć na rekompensatę potencjalnych

${ }^{90}$ Irański generał i dowódca sił Quds - sił specjalnych Korpusu Strażników Rewolucji Islamskiej. Dowodził operacjami zagranicznymi tej formacji; Qassem Soleimani, https:// www.britannica.com/biography/Qassem-Soleimani (30 IX 2021).

${ }^{91}$ Informacje PAP; za: https://wgospodarce.pl/informacje/73699-trump-iran-musizrezygnowac-z-ambicji-nuklearnych (30 IX 2021).

${ }_{92}$ M. Pompeo, The Return of UN Sanctions on the Islamic Republic of Iran, https:// www.state.gov/the-return-of-un-sanctions-on-the-islamic-republic-of-iran/ (30 IX 2021).

${ }_{93} \mathrm{Na}$ sankcjach wobec Iranu straciły także polskie firmy. Na przykład w grudniu 2011 r. Iran zerwał prowadzone od 4 lat negocjacje z Polskim Górnictwem Naftowym i Gazownictwem (PGNiG) na temat kontraktu na eksploatację złóż gazu ziemnego; Nie będzie gazu z Iranu - Teheran zerwat rozmowy z PGNiG, „Gazeta Prawna”, 19 XII 
strat gospodarczych. Z kolei współpraca transatlantycka miała pozytywny wpływ na skuteczność sankcji oraz ogłoszenie programu JCPOA.

Stany Zjednoczone nie utrzymywały praktycznie żadnych stosunków gospodarczych z Iranem. Dysponowały jednak narzędziami, które mogły wpływać na światowe ceny ropy naftowej i zniechęcać państwa trzecie do korzystania z możliwości biznesowych na rynku irańskim po wycofaniu się partnerów europejskich. USA i UE miały znaczną kontrolę nad światowymi rynkami finansowymi, co było bardzo ważne w ramach skoordynowanych działań majacych na celu wywarcie nacisku na Iran, aby wynegocjować JCPOA.

Dyplomatyczna rola USA była ograniczona głównie z powodu braku spójnego stanowiska w polityce wewnętrznej (pojednawcze podejście administracji Obamy wobec konfrontacyjnej większości republikańskiej w Kongresie). W przypadku aktywności dyplomatycznej można więc uznać przywództwo europejskie. Po negocjacjach prowadzonych z Iranem od lat dziewięćdziesiątych XX w. Europejczycy zdawali sobie sprawę, że nie zrezygnuje on całkowicie z programu jądrowego. Państwa UE miały lepszą pozycję w negocjacjach, ponieważ przed wprowadzeniem ograniczeń były głównymi partnerami handlowymi i inwestycyjnymi Iranu. Obie strony były chętne do przywrócenia tych kontaktów, a UE mogła zaoferować więcej zachęt. USA w Iranie identyfikowało jako wroga, nawiązanie stabilnych stosunków gospodarczych było więc raczej nierealne.

Ze względu na odmienny harmonogram łagodzenia sankcji, zróżnicowane do nich podejście, ale przede wszystkim z powodu niestabilności na Bliskim Wschodzie w czasie prezydentury Trumpa obserwować można rozbieżności w polityce sankcji w sojuszu transatlantyckim. Europejskie rządy były otwarte na powrót do normalnych stosunków gospodarczych z Iranem, lecz potencjalnych partnerów zniechęcały amerykańskie sankcje wtórne. Amerykanie obawiali się natomiast, że sojusznicy nie byliby skłonni do ich ponownego nałożenia, w przypadku gdyby umowę naruszył Teheran. Amerykanie nie dążyli do poprawy stosunków gospodarczych z Iranem - sprawy bezpieczeństwa były dla nich priorytetowe, a rozszerzanie się wpływów irańskich w regionie było postrzegane jako poważne zagrożenie.

Konsensus transatlantycki dotyczacy sankcji wobec Iranu przestał obowiazzywać w czasie prezydentury Trumpa. Neorealiści twierdzili, że współpraca międzynarodowa jest oparta na ocenie korzyści z niej

2011, https://biznes.gazetaprawna.pl/artykuly/577190,nie-bedzie-gazu-z-iranu-teheranzerwal-rozmowy-z-pgnig.html (30 IX 2021). 
wypływajacych, które powinny być mniej więcej równe dla wszystkich stron (relative gains) ${ }^{94}$. Wycofanie się USA z JCPOA wynikało z przekonania, że żaden z celów ich polityki wobec Iranu nie został osiagnięty. Można to stwierdzić poprzez ocenę skuteczności sankcji w percepcji obu stron na podstawie schematu zaproponowanego przez F. Giumellego. Umieszczając cele sankcji w szerszym kontekście polityki zagranicznej, można przedstawić je zgodnie z hierarchia priorytetów dla USA i UE (zob. tab. 2). Hierarchia celów została ustalona na podstawie metody zaproponowanej przez L. Jonesa i C. Portelę (zob. wstęp).

Tabela 2. Cele sankcji wobec Iranu zgodnie z priorytetami USA i UE

\begin{tabular}{|c|c|c|}
\hline Priorytet & Stany Zjednoczone & Unia Europejska \\
\hline 1. & $\begin{array}{l}\text { Ograniczenie irańskiego programu } \\
\text { nuklearnego }\end{array}$ & $\begin{array}{l}\text { Ograniczenie irańskiego programu } \\
\text { nuklearnego }\end{array}$ \\
\hline 2. & $\begin{array}{l}\text { Wzmocnienie bezpieczeństwa } \\
\text { w regionie (bezpieczeństwo } \\
\text { sojuszników) }\end{array}$ & Przywrócenie stosunków gospodarczych \\
\hline 3. & $\begin{array}{l}\text { Ograniczenie ekspansji wpływów } \\
\text { irańskich w regionie }\end{array}$ & $\begin{array}{l}\text { Wzmocnienie bezpieczeństwa } \\
\text { w regionie }\end{array}$ \\
\hline 4. & Ochrona praw obywateli irańskich & Ochrona praw obywateli irańskich \\
\hline 5. & Nawiązanie relacji gospodarczych & $\begin{array}{l}\text { Ograniczenie ekspansji wpływów } \\
\text { irańskich w regionie }\end{array}$ \\
\hline
\end{tabular}

Źródło: oprac. własne.

Chociaż oficjalnie negocjacje nad JCPOA dotyczyły tylko irańskiego programu nuklearnego, pozostałe cele były również istotne dla państw Zachodu. Liczono na ich stopniowa realizację już po podpisaniu porozumienia. Jeśli weźmiemy pod uwagę inne alternatywne sposoby osiągnięcia pierwszego, priorytetowego celu, użycie siły militarnej nie było brane pod uwagę ani przez USA, ani przez UE. Narzędzia dyplomatyczne, jak również zachęty gospodarcze były stosowane przez UE bez spodziewanego efektu. Dlatego zastosowanie skoordynowanych sankcji gospodarczych wraz z negocjacjami można uznać za najlepszą alternatywę. Przyniosły one sukces w postaci porozumienia JCPOA.

Jednak USA i UE różniły się w ocenie realizacji zamierzeń. Zdaniem przywódców UE najważniejszy wspólny cel - ograniczenie irańskiego wojskowego programu jądrowego - został osiagnięty. W lipcu 2016 r. MAEA stwierdziła, że Iran wdraża porozumienie zgodnie z umowa ${ }^{95}$. Jednak krytyka Kongresu, a następnie prezydenta USA i wycofanie się

${ }_{94}$ K. Waltz, Man, the State, and War. A Theoretical Analysis, New York 1959, s. 198.

${ }_{95}$ Verification and Monitoring... 
z JCPOA świadczyło, że Amerykanie mieli odmienne zdanie. Jeśli chodzi o zwiększenie bezpieczeństwa w regionie, to według sojuszników USA na Bliskim Wschodzie Irańczycy mogli bez trudu kontynuować program nuklearny $\mathrm{w}$ tajemnicy, pomimo kontroli MAEA, i wznowić go po zakończeniu JCPOA. Obama próbował złagodzić te obawy, ale Trump w pełni zgadzał się ze stanowiskiem Arabii Saudyjskiej i Izraela ${ }^{96}$. Poza tym od czasu uzgodnienia JCPOA Iran przeprowadził kilka testów rakietowych, a ich częstotliwość wzrosła w 2017 r. ${ }^{97}$

Państwa zachodnie nie zdołały także zatrzymać dążeń Iranu do rozszerzania wpływów w regionie. Iran był zaangażowany w wojnę zastępcza (proxy war) z Arabia Saudyjską w Jemenie. Wspierał również reżim Baszara al-Assada w Syrii, a także partię Hezbollah, której militarne skrzydło UE i USA uważały za organizację terrorystyczna. Eskalacja aktywności Iranu mogła być wywołana wroga polityką wobec Teheranu za prezydentury Trumpa. Trudno natomiast stwierdzić, czy w przypadku pozostania USA w JCPOA Iran zaniechałby takich działań.

Biorac pod uwage problem nieprzestrzegania praw człowieka przez Iran, wysiłki Zachodu można ocenić jako porażkę. USA i UE utrzymywały $\mathrm{w}$ mocy sankcje związane $\mathrm{z}$ ta kwestia. $\mathrm{Z}$ drugiej strony należy zauważyć, że jest to cel niemożliwy do osiagnięcia w tak krótkim czasie.

Było mało prawdopodobne, że Stany Zjednoczone odnowią relacje gospodarcze z Iranem, nie mając z tym państwem nawet stosunków dyplomatycznych. Sytuacja UE była odmienna - zaraz po podpisaniu porozumienia podjęto energiczne działania gospodarcze. Jednak wiele europejskich firm planujacych na nowo nawiazzać kontakty z Iranem było aktywnych również na rynku amerykańskim. Stanęły więc przed groźbą amerykańskich sankcji wtórnych. Rozbieżności na tym polu sprawiły, że współpraca europejsko-amerykańska w sprawie irańskiego programu nuklearnego za prezydentury Trumpa przestała istnieć.

UE zdecydowała się angażować w JCPOA, ponosiła więc odpowiedzialność za jego monitorowanie bez amerykańskiego wsparcia. Stany Zjednoczone natomiast wróciły do etapu sprzed skoordynowanych z UE sankcji. Współpraca transatlantycka ma jednak znaczenie w przypadku naruszenia porozumienia przez Iran. Brak jedności transatlantyckiej mógłby doprowadzić do dewaluacji sankcji gospodarczych jako narzędzia

${ }^{96}$ F.G. Gause, The Future of U.S.-Saudi Relations. The Kingdom and the Power, „Foreign Affairs” 95, 2016, nr 4, s. 114-126.

${ }_{97}$ Iran Missile Milestones: 1985-2021, 29 VII 2021 r., http://www.iranwatch.org/ our-publications/weapon-program-background-report/iran-missile-milestones-1985-2017 (30 IX 2021). 
polityki zagranicznej - alternatywy dla działań militarnych. Aby sankcje były skuteczne, obie strony powinny być więc przygotowane i przekonane do konieczności realizacji takiego scenariusza. USA wprowadziły sankcje jednostronnie, ale można stwierdzić na podstawie doświadczeń z przeszłości, że takie działania nie byłyby skuteczne w ograniczaniu irańskiego programu jądrowego. Aby realizować cele, obie strony musiałyby uznać interesy partnerów. W innym przypadku skoordynowane działania okazałyby się stratą czasu i pieniędzy.

\section{Bibliografia}

Adebahr C., Europe and Iran. The Nuclear Deal and Beyond, London-New York 2017.

Ambrose S.E., Rise to Globalism. American Foreign Policy since 1938, New York 1993.

Bloomfield L.P., Crisis Management Outside the NATO Area. Allies or Competitors?, w: Allies in a Turbulent World. Challenges to U.S. And Western European Cooperation, red. F.A.M. Alting von Geusau, Lexington 1982, s. $49-62$.

Cronberg T., No EU, No Iran Deal. The EU's Choice between Multilateralism and the Transatlantic Link, „The Nonproliferation Review” 24, 2017, nr 3-4, s. 243-259.

Dupont P., The EU-Iran Dialogue in the Context of the Ongoing Nuclear Crisis, „The Central European Journal of International and Security Studies” 3, 2010, nr 1, s. 97-112, http://www.cejiss.org/issue-detail/the-eu-iran-dialoguein-the-context-of-the-ongoing-nuclear-crisis (30 IX 2021).

Fiedler R., Iran a reżim nieproliferacji broni jadrowej. Dylematy $i$ wyzwania, Poznań 2013.

Galtung J., On the Effects of International Economic Sanctions. With Examples from the Case of Rhodesia, „World Politics” 19, 1967, nr 3, s. 378-416.

Giumelli F., The Success of Sanctions. Lessons Learned from the EU Experience, Farnham 2013.

Gul A.A., Iran's Pursuit of Peaceful Nuclear Technology, „Pakistan Horizon” 65, 2012, nr 1, s. 35-52.

Guzansky Y., Shapir Y.S., Iran Goes Ballistic, „Middle East Quarterly” 22, 2015, nr 1, s. 1-12.

Jentleson B.W., Effective Multilateralism. A US Perspective, w: Effective Multilateralism. Through the Looking Glass of East Asia, red. J. Prantl, New York 2013, s. 90-108.

Jones L., Portela C., Evaluating the "Success" of International Economic Sanctions. Multiple Goals, Interpretive Methods and Critique, „Research Collection School of Social Sciences" 2014, nr 1671, https://ink.library.smu.edu. sg/cgi/viewcontent.cgi?article=2928\&context=soss_research (30 IX 2021). 
Katzman K., Iran Sanctions, Congressional Research Service, 31 V 2013 r., http://www.fas.org/sgp/crs/mideast/RS20871.pdf (30 IX 2021).

Katzman K., Iran Sanctions, Congressional Research Service, 19 VIII 2014 r., http://fas.org/sgp/crs/ mideast/RS20871.pdf (30 IX 2021).

Katzman K., Iran Sanctions, Congressional Research Service, 23 III 2016 r., https://www.fas.org/sgp/ crs/mideast/RL32048.pdf (30 IX 2021).

Kozhanov N.A., U.S. Economic Sanctions against Iran. Undermined by External Factors, „Middle East Policy Council” 18, 2011, nr 3, s. 144-160, http:// www.mepc.org/journal/middle-east-policy-archives/us-economic-sanctionsagainst-iran-undermined-external-factors?print (25 VII 2014); http://trade. ec.europa.eu/doclib/docs/2006/september/ tradoc_113392.pdf (21 IX 2014).

LaFeber W., The American Age. United States Foreign Policy at Home and Abroad since 1750, New York 1989.

Léonard S., Kaunert Ch., "Between a Rock and a Hard Place?” The European Union's Financial Sanctions Against Suspected Terrorists, Multilateralism and Human Rights, „Cooperation and Conflict” 47, 2012, nr 4, s. 473-494.

Litwak R.S., Rogue States and US Foreign Policy. Containment after the Cold War, Washington 2000.

Lohmann S., The Convergence of Transatlantic Sanction Policy Against Iran, „Cambridge Review of International Affairs” 29, 2016, nr 3, s. 930-951.

Matera P., Matera R., Why Does Cooperation Work or Fail? The Case of EU-US Sanction Policy Against Iran, „Croatian International Relations Review” 25 (85), 2019, s. 30-62.

Meyer J.E., Second Thoughts on Secondary Sanctions, „University of Pennsylvania Journal of International Law” 30, 2009, nr 3, s. 905-968.

Patterson R., EU Sanctions on Iran. The European Political Context, „Middle East Policy" 20, 2013, nr 1, s. 135-146.

Pieper M., The Transatlantic Dialogue on Iran. The European Subaltern and Hegemonic Constraints in the Implementation of the 2015 Nuclear Agreement with Iran, „European Security” 26, 2017, nr 1, s. 99-119.

Rivlin P., Leverage of Economic Sanctions. The Case of US Sanctions Against Iran, 1979-2016, w: Geo-economics and Power Politics in the $21^{\text {st }}$ Century. The Revival of Economic Statecraft, red. M. Wigell, S. Scholvin, M. Aaltola, London-New York 2019, s. 99-113.

Rosenberger L., Economic Statecraft and US Foreign Policy, London 2020.

Sadat M.H., Hughes J.P., U.S.-Iran Engagement Through Afghanistan, „Middle East Policy Council” 17, 2010, nr 1, s. 31-51.

Shambaugh G.E., States, Firms, and Power. Successful Sanctions in United States Foreign Policy, New York 1999.

Skodlarski J., Matera R., Gospodarka światowa. Geneza i rozwój, Warszawa 2004.

Therme C., Iran and Iraq. Between Reconstruction and Containment, w: The Neighbours of the European Union's Neighbours. Diplomatic and Geopolitical Dimension Beyond the European Neighbourhood Policy, red. S. Gstöhl, E. Lannon, London 2016, s. 145-166. 
Van de Graaf T., The "Oil Weapon" Reversed? Sanctions against Iran and U.S. - EU Structural Power, „Middle East Policy” 20, 2013, nr 3, s. 145-163. Waltz K., Man, the State, and War. A Theoretical Analysis, New York 1959.

\section{Paulina Matera}

Rafał Matera

Forty years of sanctions against Iran. Analysis of political and economic causes and effects: 1979-2019

(Summary)

The article assesses the effectiveness of sanctions administered by Western countries against Iran over a period of forty years (1979-2019). It presents the motives for their introduction by the United States, European countries, and the United Nations. The purpose of the article is to test the hypothesis that individual U.S. sanctions do not have the expected effect of Iran meeting the demands of the West. On the other hand, transatlantic cooperation in this regard makes the sanctions so severe that the Tehran regime is willing to make concessions. Coordinated sanctions led to the signing of the Joint Comprehensive Plan of Action (JCPOA), an agreement limiting the development of Iran's nuclear programme, on July 14, 2015. However, in May 2018, U.S. President Donald Trump announced the withdrawal of the United States from the JCPOA and the reinstatement of all sanctions that had been in force before its signing. The Unites States' withdrawal from the JCPOA was based on the belief that none of the objectives of its policy towards Iran had been achieved. This ultimately led to Iran's announcement in January 2020 that it would resume uranium enrichment, confirming the hypothesis of the need for transatlantic cooperation in administering sanctions aimed at halting Iran's nuclear programme.

Paulina Matera - dr hab., prof. Uniwersytetu Łódzkiego. Kierowniczka Katedry Amerykanistyki i Mass Mediów na Wydziale Studiów Międzynarodowych i Politologicznych UŁ. Przewodnicząca Sekcji Międzynarodowej Ekonomii Politycznej Polskiego Towarzystwa Studiów Międzynarodowych. Zainteresowania badawcze: współczesne stosunki międzynarodowe, ze szczególnym uwzględnieniem tematyki związanej z economic statecraft, polityka zagraniczna USA, teoria i praktyka sankcji w XXI w. Wybrane publikacje: Francja $w$ polityce zagranicznej Stanów Zjednoczonych w latach 1929-1933, Toruń 2003; Stany Zjednoczone i Europa. Stosunki polityczne i gospodarcze 1776-2004 (wraz z R. Matera), Warszawa 2007; Uwarunkowania ekonomiczne polityki Stanów Zjednoczonych wobec Europy Zachodniej za prezydentury Richarda M. Nixona (1969-1974), Łódź 2012. 
Paulina Matera - PhD, associate professor at the University of Łódź. Chair of the Department of American Studies and Mass Media, Faculty of International and Political Studies. Head of International Section of Political Economics of the Polish Association of International Studies. Her research interests concern contemporary international political and economic relations, U.S. foreign policy, theory and practice of economic sanctions in the twenty-first century. She is the author of the books: Francja w polityce zagranicznej Stanów Zjednoczonych w latach 1929-1933, Toruń, 2003; Stany Zjednoczone i Europa. Stosunki polityczne i gospodarcze 1776-2004 (co-authored with R. Matera), Warsaw, 2007; Uwarunkowania ekonomiczne polityki Stanów Zjednoczonych wobec Europy Zachodniej za prezydentury Richarda M. Nixona (1969-1974), Łódź, 2012.

E-mail: paulina.matera@uni.lodz.pl

Rafal Matera - dr hab., prof. Uniwersytetu Łódzkiego. Kierownik Katedry Historii Myśli Ekonomicznej i Historii Gospodarczej, dziekan Wydziału Ekonomiczno-Socjologicznego UŁ. Członek Zarządu Polskiego Towarzystwa Historii Gospodarczej. Zainteresowania badawcze: historia gospodarcza, historia myśli ekonomicznej, relacje transatlantyckie. Wybrane publikacje: Integracja ekonomiczna krajów nordyckich, Toruń 2001; Gospodarka światowa. Geneza i rozwój (wraz z J. Skodlarskim), Warszawa 2004; Stany Zjednoczone i Europa. Stosunki polityczne i gospodarcze 1776-2004 (wraz z P. Matera), Warszawa 2007; G8 jako instytucja gospodarki światowej, Łódź 2009; Ethics in Economic Thought. Selected Issues and Various Perspectives (wraz z J. Dzionek-Kozłowska), Łódź-Kraków 2015.

Rafał Matera - PhD, associate professor at the University of Łódź. Chair of the Department of History of Economic Thought and Economic History. Dean of the Faculty of Economics and Sociology. Member of the Board of Directors of the Polish Association of Economic History. His research interests focus on economic history, history of economic thought, transatlantic relations. Among his numerous publications there are: Integracja ekonomiczna krajów nordyckich, Torun, 2003; Gospodarka światowa. Geneza i rozwój (co-authored with J. Skodlarski), Warsaw, 2004; Stany Zjednoczone i Europa. Stosunki polityczne i gospodarcze 1776-2004 (co-authored with P. Matera), Warsaw, 2007; G8 jako instytucja gospodarki światowej, Łódź, 2009; Ethics in Economic Thought. Selected Issues and Various Perspectives (co-authored with J. Dzionek-Kozłowska), Łódź-Kraków, 2015.

E-mail: rafal.matera@uni.lodz.pl 